\title{
Pteropoda (Mollusca, Gastropoda, Thecosomata) from the Paleocene-Eocene Thermal Maximum (United States Atlantic Coastal Plain)
}

\author{
Arie W. Janssen, Jocelyn A. Sessa, and Ellen Thomas
}

\begin{abstract}
The response of many organisms to the Paleocene-Eocene Thermal Maximum (PETM; 56 Ma) has been documented, but marine mollusks are not known from any deposits of that age. For the first time, we describe a PETM assemblage of pteropods (planktic mollusks), consisting of six species representing three genera (Altaspiratella, Heliconoides and Limacina). Four species could be identified to species level, and one of these, Limacina novacaesarea sp. nov., is described as new. Only the genus Heliconoides was previously known from pre-Eocene sediments, with a single Campanian specimen and one latest Paleocene species. We recovered pteropods from the Marlboro Clay (United States Atlantic Coastal Plain), deposited at paleodepths from inner shelf (southern Salisbury Embayment) to middle-outer shelf (New Jersey Coastal Plain). Most living pteropod assemblages inhabit water depths of $200 \mathrm{~m}$ or more, so their occurrence at shelf depths may reflect transport from more open waters. During the PETM, pH in the upper waters of the ocean may have declined, but this did not cause dissolution of pteropods before they reached the seafloor, possibly due to buffering in coastal waters. The apparently sudden appearance of three genera could reflect better preservation due to high sedimentation rates, since the underlying and overlying formations show poor preservation of calcareous microfossils. Potential ancestors, however, have not been found anywhere, so we consider it more likely that the rapid environmental changes during the PETM, such as temperature, runoff and nutrient fluxes, and ocean water chemistry, may have triggered pteropod diversification.
\end{abstract}

Arie W. Janssen. Naturalis Biodiversity Center, P.O. Box 9517, 2300 RA Leiden, The Netherlands. ariewjanssen@gmail.com

Jocelyn A. Sessa. Division of Paleontology, American Museum of Natural History, New York, NY, USA jsessa@amnh.org

Ellen Thomas. Department of Geology and Geophysics, Yale University, New Haven CT, USA, and Department of Earth and Environmental Sciences, Wesleyan University, Middletown, CT, USA ellen.thomas@yale.edu

Keywords: PETM; Ypresian; New Jersey Coastal Plain; Pteropoda; new species

Submission: 6 June 2016 Acceptance: 18 October 2016

http://zoobank.org/1A576936-5763-4ADE-8409-6A4AC949B85B

Janssen, Arie W., Sessa, Jocelyn A., and Thomas, Ellen. 2016. Pteropoda (Mollusca, Gastropoda, Thecosomata) from the Paleocene-Eocene Thermal Maximum (United States Atlantic Coastal Plain). Palaeontologia Electronica 19.3.47A: 1-26 palaeo-electronica.org/content/2016/1662-pteropoda-from-the-usa-petm 


\section{INTRODUCTION}

The early Paleogene was a climatically dynamic period, with relatively rapid global warming events, called hyperthermals, superimposed on a warm, greenhouse climate-state background (Zachos et al., 2001, 2008). The most extreme hyperthermal is the Paleocene-Eocene Thermal Maximum (PETM) (Kennett and Stott, 1991; Thomas and Shackleton, 1996; Zachos et al., 2008), marked by a globally recorded negative carbon isotope excursion (CIE; Thomas and Shackleton, 1996; Mclnerney and Wing, 2011), the base of which marks the Paleocene-Eocene (P-E) boundary (Dupuis et al., 2003; Aubry et al., 2007). The PETM is characterized by worldwide $5-8^{\circ} \mathrm{C}$ warming of the Earth's surface and deep oceans (Mclnerney and Wing, 2011; Dunkley Jones et al., 2013). Sea surface temperature records from the New Jersey Coastal Plain, USA, indicate up to $8^{\circ} \mathrm{C}$ local warming during the early stages of the PETM, with peak temperatures in excess of $33^{\circ} \mathrm{C}$ (Zachos et al., 2006, 2007; John et al., 2008). During the PETM, severe carbonate dissolution was widespread in the deep sea (Thomas, 1998; Zachos et al., 2005), and $\mathrm{pH}$ values declined in the upper waters of the oceans (the mixed layer) globally (Penman et al., 2014), and in the New Jersey Coastal Plain (Babila et al., 2016). Bottom waters in many coastal and marginal basins became anoxic or hypoxic (Mclnerney and Wing, 2011; Sluijs et al., 2014), including hypoxia in the New Jersey Coastal Plain (Gibson et al., 1993; Kopp et al., 2009; Stassen et al., 2015), regions along the Tethyan margins (Schulte et al., 2011; Dickson et al., 2014), and the Gulf Coastal Plain (Alabama, Mississippi, Louisiana, and Texas), USA (Sluijs et al., 2014). Oxygen Minimum Zones in open oceans may have expanded (Zhou et al., 2014).

Environmental changes during the PETM thus include abrupt warming, ocean acidification, deoxygenation, and repartitioning of nutrients in the oceans, with increased coastal nutrient fluxes and declining nutrient fluxes in open ocean due to increased stratification (Thomas, 1998; Gibbs et al., 2006; Winguth et al., 2012). These changes were associated with major evolutionary changes in the marine biosphere (Speijer et al., 2012), including the extinction of common, cosmopolitan deep-sea benthic foraminifera (e.g., Thomas, $1989,1998,2007)$, whereas the deep-sea metazoan ostracoda were less affected (e.g., Webb et al., 2009). The effect of the PETM on benthic foraminiferal communities was much less severe in shelf settings, including the New Jersey Coastal
Plain (Gibson et al., 1993; Stassen et al., 2012a, 2012b, 2012c, 2015), but carbonate platform communities saw a turnover of larger foraminifera (e.g., Scheibner et al., 2005; Scheibner and Speijer, 2008). Planktic communities show latitudinal migrations and rapid evolutionary turnover (e.g., Kelly et al., 1996; Bralower, 2002; Gibbs et al., 2006a, 2006b; Schneider et al., 2013), with an acme of the dinoflagellate Apectodinium at middle and high latitudes (e.g., Crouch et al., 2001; Sluijs et al., 2007; Sluijs and Brinkhuis, 2009). A prominent increase in the number of marine vertebrate families resulted in the appearance of earliest representatives of several extant lineages of marine fish, e.g., Gymnodonta (Bannikov et al., 2016).

The PETM therefore had profound effects on terrestrial and open ocean ecosystems, but the response of marine mollusk communities is not as well understood, in large part because no assemblages are currently known from the PETM itself. Turnover between Gulf Coastal Plain late Paleocene (NP9) and early Eocene (NP10) benthic mollusks (i.e., bivalves and benthic gastropods) is unexceptional compared to other boundaries in the Paleogene (Dockery, 1998), and richness and a variety of ecologic parameters of these assemblages are similar, with no net changes evident across the PETM (see Paleogene time bins in Sessa et al., 2012).

Pteropods are marine holoplanktic gastropods that are systematically subdivided into two major groups (orders), the Thecosomata and Gymnosomata, of which only the former, with c. 80-85 modern species, have thin-walled aragonitic shells in the adult stage of most species. Thecosomatous pteropods are found in all the world's oceans, but are much more diverse in tropical than in polar waters, although in the latter their biomass is larger (Bednaršek et al., 2012a). Along with temperature, productivity is a strong control on their distribution, and pteropod oozes are generated from highly productive surface waters. Their thin, fragile shells might be protected against dissolution by the organic outer layer (Peck et al., 2016), but they have been argued to rapidly dissolve in waters not supersaturated with aragonite, and they play an important role in current studies of ocean acidification (e.g., Bednaršek and Ohman, 2015 and references therein).

Thecosomatous pteropods generally have a wide geographic, but restricted stratigraphic distribution, making them useful in biostratigraphy (Janssen and King, 1988; Gürs and Janssen, 2004; Janssen, 2012), including long-distance cor- 


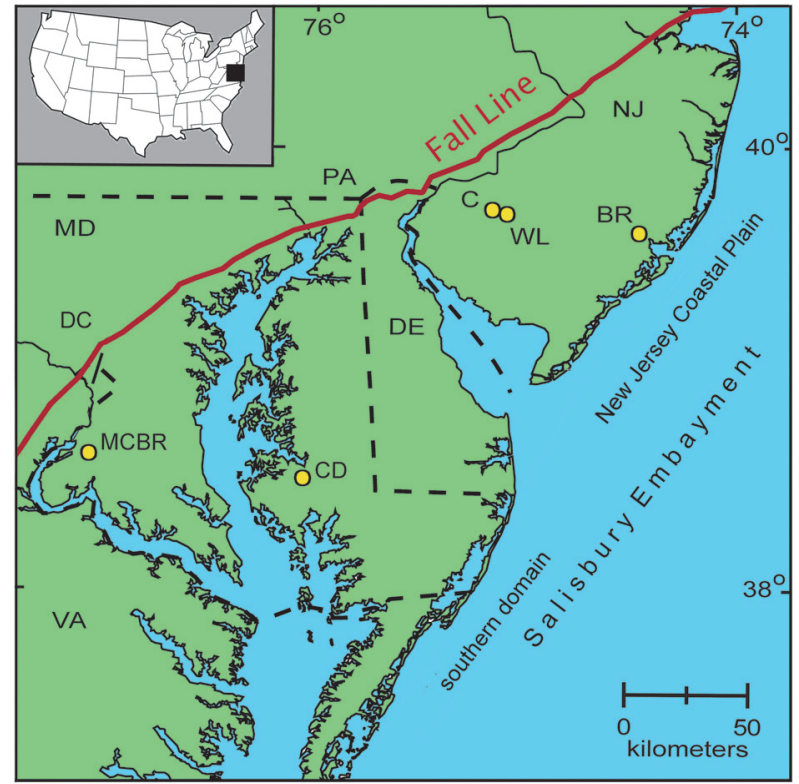

FIGURE 1. Map of the northeastern coast of the USA, showing part of the northern portion of the Atlantic Coastal Plain and the location of the studied cores: $B R=$ Bass River; $C=$ Clayton; $W L=$ Wilson Lake; $C D=$ Cambridge-Dorchester; MCBR = Mattawoman Creek-Billingsley Road. The New Jersey Coastal Plain is the northern section of the Salisbury Embayment. In outcrop, the Fall Line marks the change from Precambrian and Paleozoic rocks of the Piedmont province in the west to the relatively undeformed, slightly dipping Mesozoic and Cenozoic sediments of the Coastal Plain in the east (Gibson and Bybell, 1994). For visual ease, the New Jersey Coastal Plain and the Salisbury Embayment labels are delineated offshore.

relations (Janssen, 1990; King, 2016). Their fossil record is well documented from the Eocene on, although little is known about their possibly Cretaceous origins.

The fossilization of pteropods requires specific conditions. Sediments in the Mediterranean and Red Seas preserve pteropods due to a combination of warm bottom waters (which enhance precipitation and preservation of aragonite in the sediments) and high sedimentation rates (Herman, 1978). Paleogene pteropods are typically preserved as internal molds, although in some cases original shells have been recovered (e.g., Collins, 1934; Curry, 1982; Hodgkinson et al., 1992; Cahuzac and Janssen, 2010). Nearly 50 species of Eocene pteropods are known from the Gulf Coastal Plain (Collins, 1934; Palmer and Brann, 1965; Hodgkinson et al., 1992). Prior to this study, only one Paleocene pteropod species was known from the Gulf Coastal Plain (Janssen, 2010); none were known from Paleocene or Eocene of the con- tiguous Atlantic Coastal Plain, which contains the New Jersey Coastal Plain. Here, we document that pteropods along the Atlantic Coastal Plain were quite diverse during the PETM, and we describe their assemblages.

\section{Geological Setting}

The Atlantic Coastal Plain is a region of low physiographic relief along the eastern coast of the USA, spanning from the state of Massachusetts in the north to the state of Florida in the south.

It is composed of a series of embayments and arches, including the Salisbury Embayment between the Norfolk Arch and the South Jersey high (Gibson and Bybell, 1994; Kopp et al., 2009). The Salisbury Embayment is divided into a southern domain (Maryland, Virginia, and Delaware) and the northern domain of the New Jersey Coastal Plain (Figure 1).

The Salisbury Embayment was the site of intermittent marine onlap and deposition in a primarily terrestrial setting from the Early Cretaceous through most of the Paleogene. Beds of fluval, deltaic, and open-shelf origin were deposited in a wedge-like, thickening seaward configuration. The most proximal core studied, the Mattawoman Creek-Billingsley Road core 2 (MCBR2; Self-Trail et al., 2013) is located near the western edge of the Embayment; the Cambridge-Dorchester core is more centrally located (Figure 1). The Paleocene upper Aquia Formation in the Salisbury Embayment consists of greenish black, clayey, and silty glauconitic quartzose sands, and is interpreted to represent inner and middle neritic environments (e.g., Nogan, 1964; Self-Trail et al., 2012, and references therein). The overlying, lowermost Eocene Marlboro Clay is composed of light gray to pinkish grey and reddish brown silty clays dominated by kaolinite, indicative of high fluvial influx (e.g., Gibson and Bybell, 1994; Gibson et al., 2000; SelfTrail et al., 2012). In the Cambridge-Dorchester core, the PETM has been identified by the negative shift in carbon isotopes and the presence of excursion planktic foraminifera (Livsey, 2015). In MCBR2, the PETM is identified by the negative shift in carbon isotopes, excursion dinoflagellates and calcareous nannoplankton, and an increase in the percent abundance of fern spores (Willard et al., 2009; Self-Trail et al., 2013).

The Clayton, Wilson Lake, and Bass River drill sites are located in the New Jersey Coastal Plain, which contains one of the most complete North Atlantic records of shallow marine Paleocene-Eocene boundary deposition (Olsson and 
Wise, 1987; Gibson et al., 1993; Gibson and Bybell, 1994). In these cores, the upper Paleocene Vincentown Formation is correlative to the Aquia Formation, but is generally more fine-grained, and consists of green-to-brown, glauconitic quartz sands updip (closest to the paleo-shoreline), changing downdip (further away from the paleoshoreline) to more fine-grained, glauconitic quartzose silts and clays. The lower Eocene Manasquan Formation generally consists of yellow-green to olive-green, massive calcareous clay/silts to very fine sands (Olsson and Wise, 1987). A thick kaolinite-rich, clayey layer with rare or without glauconite is intercalated between the lithologies typical of the Vincentown and Manasquan Formations, and was originally described as the 'unnamed clay unit' in the lower Manasquan Formation (Olsson and Wise, 1987; Gibson et al., 1993; Gibson et al., 2000). This unit is currently named the Marlboro Clay (being coeval to the sediment in the southern Salisbury Embayment), and is the lowest member of the Manasquan Formation (Kopp et al., 2009), now recognized as the regional expression of the PETM (e.g., Gibson et al., 1993, 2000; Cramer et al., 1999; Harris et al., 2010; John et al., 2012; Self-Trail et al., 2012; Stassen et al., 2012b, 2014). The PETM clays are unconformably overlain by glauconitic clays to clayey silts of the higher Manasquan Formation (Olsson and Wise, 1987). We use the age model of Stassen et al. (2012c, 2015).

The Marlboro Clay contains very well-preserved, glassy planktic and benthic foraminifera (Gibson et al., 1993; Zachos et al., 2006, 2007; Stassen et al., 2012a, b, c; 2015), in sharp contrast with the glauconitic, sandy underlying Vincentown Formation, and overlying parts of the Manasquan Formation, which contain poorly preserved, commonly broken benthic assemblages, and generally rare, poorly preserved (Bass River) planktic foraminifera with very low diversity, or planktic foraminifera are absent (Clayton, Wilson Lake; Gibson et al., 1993, 2000). Calcareous nannofossil (Aubry et al., 2000; Gibbs et al., 2006a, 2006b; Bybell, personal commun., 2013) and stable isotope records (Cramer et al., 1999; Zachos et al., 2006, 2007; John et al., 2008) provide the main stratigraphic framework, supported by a sequence of bioevents (Sluijs and Brinkhuis, 2009; Stassen et al., 2012b, 2012c). The sedimentation rates of the Marlboro Clay were much higher than those of the Vincentown and Manasquan Formations (e.g., Olsson and Wise, 1987; Gibson et al., 2000; John et al., 2008; Harris et al., 2010; Stassen et al., 2012c).
Bass River is approximately $35 \mathrm{~km}$ down-dip along the basin gradient (Olsson and Wise, 1987), in waters estimated to have been about $35 \mathrm{~m}$ deeper than at Wilson Lake and Clayton (e.g., Harris et al., 2010; Figure 1). Benthic assemblages indicate a late Paleocene paleodepth for Wilson Lake and Clayton of around 100-110 m, for Bass River of $\sim 140-150 \mathrm{~m}$, with sea level rising by about 20-30 $\mathrm{m}$ during the transition into the PETM (Sluijs et al., 2008; Stassen et al., 2012c, 2015). Others consider that the paleodepths were considerably less, i.e., $39 \mathrm{~m}$ for Clayton and Wilson Lake during the PETM, $73 \mathrm{~m}$ for Bass River (Wright and Schaller, 2013; see also Harris et al., 2010).

\section{MATERIALS AND METHODS}

Wilson Lake (Gloucester County, New Jersey, USA), cored borehole of United States Geological Survey (USGS), coordinates N39 $39^{\prime} 21^{\prime \prime}$, W75 02'31", drilled 2000. Samples from the Marlboro Clay (Eocene, Ypresian), as well as underlying and overlying glauconitic sands and silts, were analyzed for microfossils in the interval of 91.74 to $112.78 \mathrm{~m}$. Samples yielding pteropods are specified in Table 1.

Bass River (Burlington County, New Jersey, USA), cored borehole drilled 1996, Ocean Drilling Program (ODP) leg 174X, in Bass River State Forest, $39^{\circ} 36^{\prime} 42^{\prime \prime} \mathrm{N}, 74^{\circ} 26^{\prime} 12^{\prime \prime} \mathrm{W}$; elevation $28 \mathrm{ft}(8.53$ m; New Gretna, NJ, 7.5-min quadrangle); drilling operations were supervised by the Scientific Drilling Office of Texas A\&M University (Miller et al., 1998). Samples from the Marlboro Clay (Eocene, Ypresian), as well as the underlying and overlying glauconitic sands and silts, were analyzed for microfossils in the interval of 347.50 to $365.64 \mathrm{~m}$. Samples yielding pteropods are specified in Table 2.

Clayton (Gloucester County, New Jersey, USA), cored borehole drilled 1988 by the USGS, Pitman East $7.5^{\prime}$ quadrangle at $39^{\circ} 39^{\prime} \mathrm{N}, 75^{\circ} 6^{\prime} \mathrm{W}$. Samples from the Marlboro Clay (Eocene, Ypresian), as well as the underlying and overlying glauconitic sands and silts, were analyzed for microfossils in the interval of 89.00 to $107.32 \mathrm{~m}$. Samples yielding pteropods are specified in Table 3.

Samples were taken from the Wilson Lake, Clayton and Bass River cores in 2007, and processed for benthic foraminiferal studies (Stassen et al., 2012a, 2012b, 2012c, 2015); all cores were dry at the time of sampling. About $20-40 \mathrm{~g}$ of dry sediment was washed over a 63- $\mu \mathrm{m}$ sieve until complete disaggregation. The complete coarse fraction 
TABLE 1. Distribution of pteropod species in the Wilson Lake section.

\begin{tabular}{|c|c|c|c|c|c|c|c|c|}
\hline $\begin{array}{l}\text { Sample } \\
\text { number }\end{array}$ & $\begin{array}{l}\text { Sample depth } \\
\text { (m) }\end{array}$ & $\begin{array}{c}\text { Age after } \\
\text { CIE onset } \\
\text { (ky) }\end{array}$ & 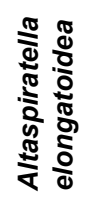 & 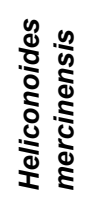 & 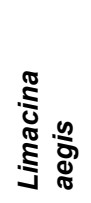 & 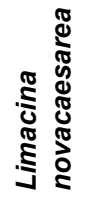 & 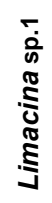 & $\begin{array}{c}\text { Nannoplankton } \\
\text { zone }\end{array}$ \\
\hline 19 & $97.23-97.29$ & 66.58 & - & 1 & - & - & - & NP10a \\
\hline 20 & $97.54-97.60$ & 65.20 & 1 & 7 & - & - & - & \\
\hline 21 & $97.84-97.90$ & 63.81 & 1 & 3 & - & - & - & \\
\hline 22 & $98.15-98.21$ & 62.43 & 2 & 2 & - & 2 & - & \\
\hline 23 & $98.45-98.51$ & 61.05 & - & 1 & - & - & - & \\
\hline 24 & $98.76-98.82$ & 59.14 & - & 3 & 1 & 1 & - & \\
\hline 25 & $99.06-99.12$ & 58.28 & - & 6 & - & - & - & \\
\hline 26 & $99.36-899.43$ & 56.90 & 1 & 3 & - & - & - & \\
\hline 27 & $99.67-99.73$ & 55.51 & - & 8 & 1 & 1 & - & \\
\hline 28 & $99.97-100.04$ & 54.13 & - & 1 & 1 & - & - & \\
\hline 29 & $100.28-100.34$ & 52.74 & - & 4 & - & - & - & \\
\hline 30 & $100.58-100.64$ & 51.36 & - & 7 & - & - & - & \\
\hline 31 & $100.89-100.95$ & 49.98 & 1 & 6 & - & - & - & \\
\hline 32 & $101.19-101.25$ & 48.57 & - & 4 & - & - & - & \\
\hline 33 & $101.50-101.56$ & 47.21 & - & 6 & - & - & - & \\
\hline 34 & $101.80-101.86$ & 45.83 & 1 & 15 & 1 & - & - & \\
\hline 36 & $102.41-102.47$ & 43.06 & - & 1 & 1 & - & - & \\
\hline 37 & $102.72-102.78$ & 41.68 & 1 & 2 & - & - & 1 & \\
\hline 39 & 103.33-103.37 & 38.91 & 1 & 8 & 1 & - & 1 & \\
\hline 40 & $103.63-103.69$ & 37.51 & - & 5 & 1 & - & 1 & \\
\hline 41 & $103.94-104.00$ & 35.70 & 3 & 1 & - & - & - & \\
\hline 42 & $104.24-104.30$ & 33.89 & 3 & 1 & - & - & - & \\
\hline 43 & $104.55-104.61$ & 32.09 & - & 3 & - & - & - & \\
\hline 45 & $105.16-105.22$ & 28.47 & - & 3 & - & - & - & \\
\hline 48 & $106.07-106.13$ & 23.05 & - & 2 & - & - & - & \\
\hline 49 & $106.38-106.44$ & 21.25 & 1 & 11 & - & - & - & NP9 \\
\hline 50 & $106.68-106.74$ & 19.43 & 2 & 13 & $1 ?$ & - & - & \\
\hline 51 & $106.98-107.05$ & 17.63 & 1 & 13 & 1 & - & - & \\
\hline 52 & $107.08-107.11$ & 17.18 & - & - & 12 & - & - & \\
\hline 53 & $107.17-107.20$ & 15.83 & 1 & - & 1 & - & - & \\
\hline 54 & $107.29-107.35$ & 17.18 & - & 4 & - & - & - & \\
\hline 56 & $107.47-107.50$ & 14.76 & - & 1 & - & - & - & \\
\hline 57 & $107.59-107.66$ & 14.02 & - & 11 & 1 & - & - & \\
\hline 58 & 107.69-107.72 & 13.57 & 2 & 3 & 1 & - & - & \\
\hline 59 & $107.78-107.81$ & 13.03 & - & 5 & 9 & - & - & \\
\hline 60 & $107.90-107.96$ & 12.21 & - & 4 & 2 & - & - & \\
\hline 61 & 107.99-108.02 & 11.76 & 2 & 1 & - & - & - & \\
\hline 62 & $108.08-108.11$ & 11.22 & - & 2 & - & - & - & \\
\hline 63 & $108.20-108.26$ & 10.41 & 3 & 12 & 2 & - & 1 & \\
\hline 65 & 108.39-108.42 & 9.41 & - & 7 & - & - & - & \\
\hline 67 & $108.60-108.63$ & 8.15 & - & 1 & - & - & - & \\
\hline 68 & 108.69-108.72 & 7.61 & 1 & 3 & 3 & - & - & \\
\hline
\end{tabular}

was checked for the presence of pteropods, and abundance of pteropods shown in Tables 1-3.

Sample spacing was $30 \mathrm{~cm}$ for most of the studied interval, up to $5-10 \mathrm{~cm}$ around the P-E boundary. Additional pteropods from two boreholes in Maryland are included in this study. Formal age models have not yet been established for these two cores.

Cambridge-Dorchester regional airport (Dorchester County, Maryland, USA) cored bore- 
hole by the USGS in 2009 , coordinates $38^{\circ} 32^{\prime} 4^{\prime \prime} \mathrm{N}$, $76^{\circ} 1^{\prime} 44^{\prime \prime}$. Samples from the upper Aquia Formation (late Paleocene, Thanetian) and the Marlboro Clay (Eocene, Ypresian) were analyzed for microfossils in the interval of 204.2 to $229.7 \mathrm{~m}$. Samples were treated with a sodium hexametaphosphate solution for two hours, washed with buffered water through a $63-\mu \mathrm{m}$ sieve, filtered through grade P5 filter paper, and oven dried at $40^{\circ} \mathrm{C}$ overnight (Livsey, 2015). Samples yielding pteropods are specified in Table 4.

Mattawoman Creek-Billingsley Road (MCBR2; Charles County, Maryland, USA) cored by the USGS in 2011 , coordinates $38^{\circ} 36^{\prime} 54.53^{\prime \prime} \mathrm{N}$, $77^{\circ} 02^{\prime} 52.12 " W$. Samples from the upper Aquia Formation (Late Paleocene, Thanetian) and the Marlboro Clay (Eocene, Ypresian) were analyzed for microfossils in the interval of 3.94 to $12.72 \mathrm{~m}$. Samples were treated with a sodium hexametaphosphate solution, washed through a $63-\mu \mathrm{m}$ sieve, and oven dried at $<50^{\circ} \mathrm{C}$ overnight. Samples yielding pteropods are specified in Table 5 .

Samples recorded herein are housed in the fossil holoplanktic mollusk collection of the Naturalis Biodiversity Center (Leiden, The Netherlands; RGM registration numbers). For all cores except MCBR2, sampling took place many years after the cores had been collected, so that most specimens (nearly all preserved as internal pyritic molds) have been oxidized, and therefore deteriorated to various degrees. To prevent further damage, all pteropods are now stored in Naturalis turntop slides (Figure 2) and covered in synthetic resin (Glyptal). For further study, specimens can easily be isolated with acetone, by which the material of the slides is not affected.

\section{Scanning Electron Microscopy}

SEM micrographs were made by Renate Helwerda from uncoated specimens at $1.000 \mathrm{kv}$ with a Jeol Field emission scanning electron microscope type: JSM-7600F of Naturalis Biodiversity Center, Leiden, The Netherlands.

\section{Computed Tomography}

Specimens were scanned using a GE PHOENIX v|tome|X s240 computed tomographic (CT) system with a $180 \mathrm{kV}$ nano tube in the Microscopy and Imaging Facility at the American Museum of Natural History, under the direction of Morgan Hill and Henry Towbin. Scan parameters ranged from 1.6 to 4.9 micrometer/voxel, and 165 to $145 \mathrm{kV}$, and the detector exposure timing was $750 \mathrm{~ms}$ for all specimens, with the specific parameters pro- vided in the figure captions of the scans. The CT data were processed and smoothed using the software program VGStudioMax 2.2. Once the surface stereo lithography mesh file was extracted from VGStudioMax, it was converted into a universal 3D object (i.e., a .u3d file) using the software Meshlab.

\section{SYSTEMATIC PALEONTOLOGY}

Systematics follow Bouchet and Rocroi (2005). Symbols used in the synonymy lists anticipating the year of publication are those of Richter (1948) and Matthews (1973):
* first valid introduction of a taxon;
responsibility for the identification is accepted by the present authors;
(no symbol) responsibility for the identification is not accepted by the present authors, but there is no reason for doubt;
? in the opinion of the present authors there is reason to doubt the identification;
$v \quad$ the original material of this reference was studied by the present authors;
[ ] (date between brackets) the year of publi- cation is uncertain (or the paper has not been published officially, e.g., thesis);
non erroneous identification, in the opinion of the present authors.
Phylum MOLLUSCA Linnaeus, 1758
Class GASTROPODA Cuvier, 1795
Subclass HETEROBRANCHIA Burmeister, 1837
Order THECOSOMATA de Blainville, 1824
Suborder EUTHECOSOMATA Meisenheimer, 1905
Superfamily LIMACINOIDEA Gray, 1847
Family LIMACINIDAE Gray, 1847
Genus ALTASPIRATELLA Korobkov, 1966 (= PLOTOPHYSOPS Curry, 1982)

Type species. 'Limacina elongatoides'[sic] (Aldrich), by original designation of Korobkov $(1966$, p. 74) $=$ Physa elongatoidea Aldrich, 1887 (Eocene, early Ypresian, Wilcox Group, Hatchetigbee Formation, Bashi Member; zone NP 10).

Type species of Plotophysops is $P$. bearnensis Curry, 1982, by original designation (Eocene, middle to late Ypresian, Marnes de Gan Formation; top NP12 to base NP13).

Altaspiratella elongatoidea (Aldrich, 1887) Figures 3.1-4, 4

v*1887 Physa elongatoidea Aldrich, p. 83.

v. 1895 Spiralis elongatoidea (Aldrich); Aldrich, p. 5 , pl. 2, fig. 9. 
TABLE 2. Distribution of pteropod species in the Bass River section.

\begin{tabular}{|c|c|c|c|c|c|c|c|c|}
\hline $\begin{array}{l}\text { Sample } \\
\text { number }\end{array}$ & $\begin{array}{l}\text { Sample depth } \\
\text { (m) }\end{array}$ & $\begin{array}{c}\text { Age after } \\
\text { CIE onset } \\
\text { (ky) }\end{array}$ & 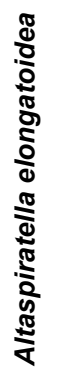 & 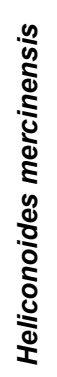 & 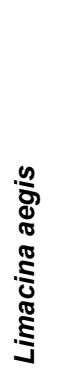 & 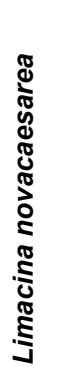 & 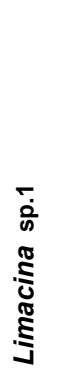 & $\begin{array}{c}\text { Nannoplankton } \\
\text { zone }\end{array}$ \\
\hline 9 & 349.94-349.97 & 87.85 & - & 2 & - & - & - & NP10a \\
\hline 13 & $351.16-351.19$ & 80.76 & 1 & 1 & - & - & - & \\
\hline 14 & $351.46-351.50$ & 78.99 & - & 1 & - & - & - & \\
\hline 16 & 352.04-352.07 & 75.62 & 1 & 7 & 3 & - & - & \\
\hline 18 & $352.65-352.68$ & 72.07 & - & - & - & $1 ?$ & - & \\
\hline 20 & $353.26-353.29$ & 67.05 & - & $1 ?$ & - & - & - & \\
\hline 24 & $354.48-354.51$ & 54.97 & 1 & - & - & - & - & \\
\hline 25 & $354.79-354.82$ & 52.03 & 3 & 2 & 1 & - & - & \\
\hline 26 & $355.09-355.12$ & 49.08 & 1 & - & 1 & - & - & \\
\hline 28 & $355.70-355.73$ & 43.34 & - & 3 & - & - & - & \\
\hline 29 & $355.98-356.01$ & 40.27 & - & 9 & - & - & - & \\
\hline 30 & $356.10-356.13$ & 39.37 & - & - & $1 ?$ & - & - & \\
\hline
\end{tabular}

TABLE 3. Distribution of pteropod species in the Clayton section.

\begin{tabular}{|c|c|c|c|c|c|c|c|c|}
\hline $\begin{array}{l}\text { Sample } \\
\text { number }\end{array}$ & $\begin{array}{l}\text { Sample depth } \\
(\mathrm{m})\end{array}$ & $\begin{array}{l}\text { Age after } \\
\text { CIE onset } \\
\text { (ky) }\end{array}$ & 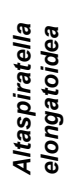 & 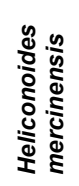 & 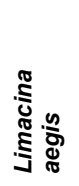 & 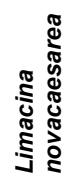 & 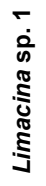 & $\begin{array}{c}\text { Nannoplankton } \\
\text { zone }\end{array}$ \\
\hline 9 & $91.44-91.47$ & 37.51 & 4 & 5 & 2 & - & 1 & NP10a \\
\hline 10 & $91.74-91.78$ & 35.71 & - & - & 1 & - & - & \\
\hline 11 & $92.05-92.08$ & 33.90 & - & 6 & - & - & - & \\
\hline 12 & $92.35-92.38$ & 32.10 & 1 & - & - & - & - & \\
\hline 14 & $92.96-92.99$ & 28.49 & - & - & - & 1 & - & \\
\hline 15 & $93.27-93.30$ & 26.69 & - & - & - & - & - & \\
\hline 17 & $94.03-94.06$ & 22.18 & - & - & 4 & - & - & NP9b \\
\hline 18 & $94.21-94.24$ & 21.10 & - & 1 & 2 & - & - & \\
\hline 19 & $94.55-94.58$ & 19.12 & - & 3 & 4 & - & - & \\
\hline 20 & $94.79-94.82$ & 17.67 & 1 & 1 & 1 & - & - & \\
\hline 21 & $95.07-95.10$ & 16.05 & - & - & 1 & - & - & \\
\hline 22 & $95.40-95.43$ & 14.07 & 3 & 4 & 2 & - & - & \\
\hline
\end{tabular}

v. 1899 Spiralis elongatoidea (Aldrich); Harris, p. ?[1986] 103, pl. 12, fig. 25.

v. 1934 Limacina elongatoides [sic] (Aldrich); Col- v. ?1990 lins, p. 177, pl. 7, fig. 1.

v. 1965 Limacina elongatoidea (Aldrich); Palmer ? 1992 and Brann, p. 358.

v. 1966 Spiratella (Altaspiratella) elongatoides [sic] (Aldrich); Korobkov, p. 74.

v. ? 1982 Plotophysops bearnensis Curry, p. 40, pl. 1, fig. 9a-c.
Spiratella tutelina Curr.; Merle, p. 43 (non Curry).

Altaspiratella bearnensis (Curry, 1981 [sic]); Janssen, p. 68.

Altaspiratella bearnensis (Curry); Hodgkinson, Garvie and Bé, p. 13, pl. 1, figs. 1, 2.

v. 1992 Altaspiratella elongatoidea (Aldrich); Hodgkinson, Garvie and Bé, p. 14, pl. 1, fig. 3.

? [1996] Altaspiratella bearnensis (Curry, 1981); Kunz, p. 164, pl. 30, figs. 1-3. 
TABLE 4. Distribution of pteropod species in the Cambridge-Dorchester section.

\begin{tabular}{|c|c|c|c|c|c|c|}
\hline $\begin{array}{l}\text { Sample } \\
\text { number }\end{array}$ & Sample depth (m) & 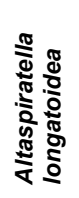 & 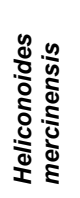 & 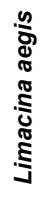 & 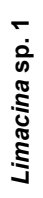 & 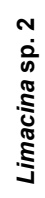 \\
\hline 8 & $214.01-214,03$ & 1 & 3 & 1 & - & - \\
\hline 10 & $215.80-215,83$ & - & 3 & - & - & - \\
\hline 12 & $217.41-217.44$ & - & 1 & 1 & - & - \\
\hline 13 & $218.50-218.51$ & - & $1 ?$ & - & - & - \\
\hline 14 & 219.30-219.33 & 1 & 4 & - & - & - \\
\hline 15 & $220.22-220.28$ & 3 & 6 & 1 & - & - \\
\hline 16 & $221.19-221.21$ & 1 & - & - & - & - \\
\hline 17 & $221.47-221.48$ & 1 & 5 & 1 & 2 & - \\
\hline 23 & $222.09-222.14$ & - & - & - & 1 & - \\
\hline 26 & 222.61-222.62 & - & - & - & - & 1 \\
\hline 33 & $223.60-223.61$ & - & - & - & - & - \\
\hline
\end{tabular}

TABLE 5. Distribution of Heliconoides mercinensis in the Mattawoman Creek-Billingsley Road core 2 section.

\begin{tabular}{ccc}
\hline Sample number & $\begin{array}{c}\text { Sample depth } \\
(\mathbf{m})\end{array}$ & $\begin{array}{c}\text { Heliconoides } \\
\text { mercinensis }\end{array}$ \\
\hline 14 & $5.15-5.20$ & $1 ?$ \\
20 & $5.74-5.80$ & 2 \\
28 & $6.55-6.60$ & 1 \\
29 & $6.65-6.70$ & 1 \\
41 & $7.85-7.90$ & $3 ?$ \\
49 & $8.65-8.70$ & 2 \\
64 & $10.15-10.20$ & $1 ?$ \\
72 & $10.94-11.00$ & $1 ?$ \\
84 & $12.17-12.22$ & 1 \\
85 & $12.27-12.32$ & $4,1 ?$ \\
\hline
\end{tabular}

v. ? $2010 \quad$ Altaspiratella bearnensis (Curry, 1982); Cahuzac and Janssen, p. 24, pl. 2, figs. 14 ; pl. 3, fig. 1.

Type material. To date exclusively known by the holotype, USNM 638862.

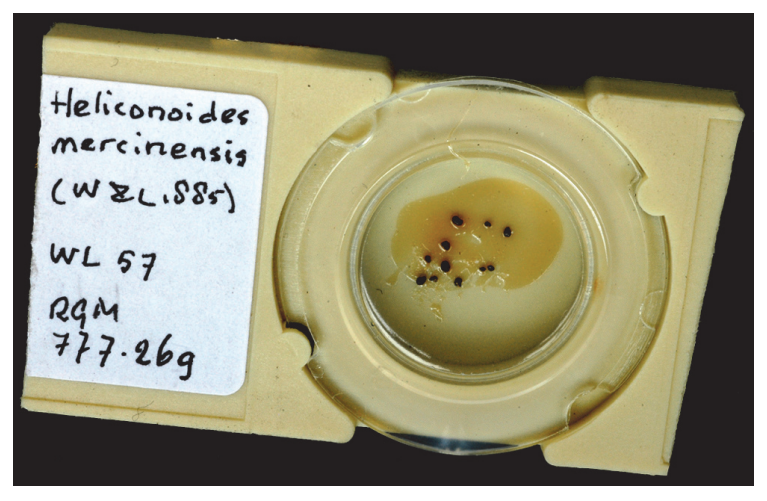

FIGURE 2. Specimen storage in the Naturalis (Leiden, $\mathrm{NL})$ fossil holoplanktic mollusk collection.
Type locality. Choctaw Corner, Clarke Co., Alabama, USA (Eocene, early Ypresian, NP 10).

Material examined. Wilson Lake section, NP 9 and NP 10a (Table 1); Bass River section, NP 10a (Table 2); Clayton section, NP 9b, 10a (Table 3); Cambridge-Dorchester section (Table 4).

Description. Shell sinistral, conical, oblong, about twice as high as wide, with up to six slightly convex, comparatively high whorls that gradually increase in diameter, separated by an incised, oblique suture. Apical angle c. $35-40^{\circ}$. The whorls attach below the periphery of the preceding whorl, where the shell may be slightly angular, especially in immature individuals. All specimens are preserved as pyritic internal molds, frequently compressed or otherwise crumpled, and no adult shell parts with developed apertural features are preserved.

Discussion. Two very similar species in this genus are Altaspiratella elongatoidea (Aldrich, 1887) and A. bearnensis (Curry, 1982). The former was intro- 


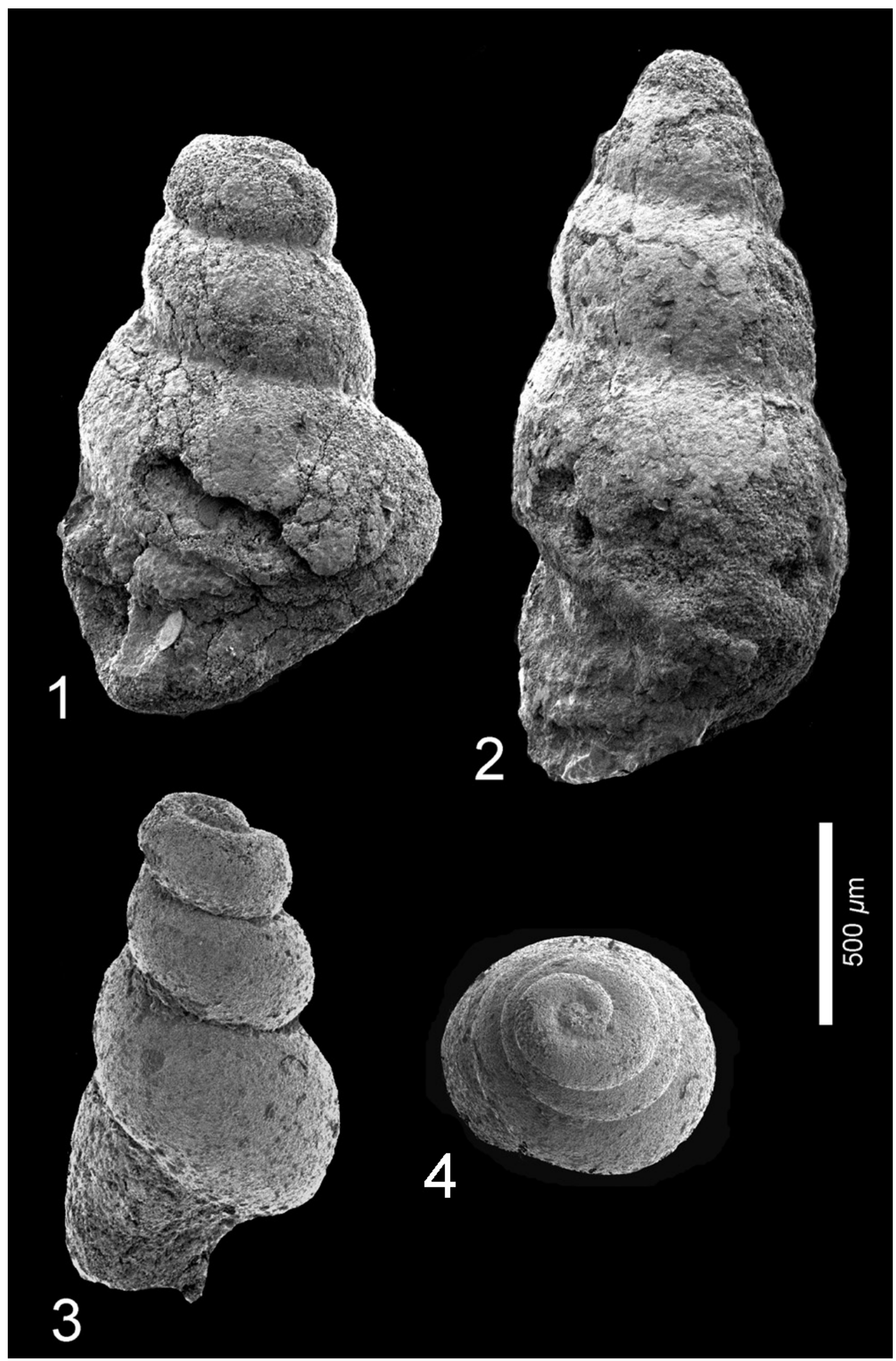

FIGURE 3. Altaspiratella elongatoidea (Aldrich, 1887). 1, Wilson Lake section, sample 31, depth 100.89-100.95 m, RGM 777 230; apertural view. 2, Clayton section, sample 9, depth 91.44-91.4 m; RGM 777 308a; apertural view. 3-4, Wilson Lake section, sample 42, depth 104.24-104.30 m; RGM 777 251a, 3: apertural view, 4: apical view. 
duced from the Ypresian of Alabama (Bashi Member of the Hatchetigbee Formation, NP 10; the marine portion of the Bashi was constrained by Sluijs et al. (2014) to lie above the CIE, and is thus younger than our samples, which are in the peak PETM interval) and was with certainty only known by its holotype. Altaspiratella bearnensis was first described from the Marnes de Gan, at Gan (Pyrénées-Atlantiques, France; Ypresian, NP 12/ 13), from where extensive material of this species is available in the Naturalis collection. Holo- and paratypes are in the Natural History Museum, London, UK (nr BMNH CG. 21255).

Hodgkinson et al. (1992, p. 13) discussed these two forms, together with another Ypresian, relatively high-spired species, Limacina tutelina (Curry, 1965), but decided to maintain them as separate taxa, stating that there is little resemblance between complete specimens, as neither of these two species has the well-developed anterior indenture so prominent in $A$. bearnensis. However, the single specimen of $A$. elongatoidea is incomplete, lacking its apertural parts, so a comparison of these structures with those in $A$. bearnensis is impossible.

Cahuzac and Janssen (2010, p. 24, pl. 2, figures $3 c$ and $5 a$ ) also discussed both Altaspiratella species and found a small difference between the type specimens. In the holotype of $A$. elongatoidea the first apical whorl is markedly wider than in the type of $A$. bearnensis, as well as in all additional specimens of that species. It was not decided whether these two taxa are synonyms, because of $A$. elongatoidea, only the holotype specimen was available. Comparison of figures 2 and 3 on plate 1 of Hodgkinson et al. (1992), respectively, identified as Altaspiratella bearnensisi and $A$. elongatoidea (holotype), however, demonstrates hardly any differences.

Similarly, all specimens recorded herein are incomplete and do not preserve adult apertural features. The small difference noted by Cahuzac and Janssen (2010), however, seems to be present in a single sufficiently well preserved immature specimen (Figure 3.4), which makes a synonymy of these two taxa less likely. Therefore, and in the absence of completely developed specimens of $A$. elongatoidea, we hesitate to consider these species identical, even if their stratigraphical ranges overlap (see below).

Distribution. Altaspiratella elongatoidea to date was only known from its type locality (NP 10). The material recorded herein demonstrates it presence immediately above the Paleocene/Eocene boundary (NP 9), continuing into zone NP 10a.

Apart from its type locality as specified above, Altaspiratella bearnensis was subsequently recorded from the 'Middle Blue Marls Formation' of Pradelle-en-Val (France, Aude department; Ypresian NP 10; Pirkenseer et al., 2013). From the North Sea Basin, the species is known from Ypresian localities in Belgium (Mont Panisel Formation, Knokke borehole), and several localities in the London and Hampshire basins (England, London Clay Formation, divisions $D$ and E, NP 10-11; King, 2016). Additional, more remote occurrences are in Egypt (Thebe Formation, Luxor, Valley of the Kings; probably NP 13; Naturalis collections) and Kazakhstan (Aktulagay; NP 12; King et al., 2013). Hodgkinson et al. (1992, text-figure 3) recorded Altaspiratella bearnensis from the Weches Formation of Texas (zone NP 15, mid-Lutetian).

\section{Genus HELICONOIDES d'Orbigny, 1835}

Type species. Atlanta inflata d'Orbigny, 1834, by subsequent designation of Herrmannsen (1846, p. $514)=$ Heliconoides inflatus (d'Orbigny, 1834) (Recent).

Heliconoides mercinensis (Watelet and Lefèvre, 1885)

Figures 5.1-3, 6

$1874 \quad$ Planorbis ikke ulig Pl. vortex men maaske en Valvatina; Mörch, p. 279.

*1885 Spirialis mercinensis Watelet and Lefèvre, p. 102, pl. 5 fig. 2a c.

1900 Valvatina raphistoma; Stolley, p. 12, figs. 1a-c, 2.

1907 Valvatina raphistoma; Ravn, p. 368.

1913 Valvatina merciniensis [sic] (Watelet and Lefèvre); Cossmann and Pissarro, caption of plate; pl. 60, Pteropodes 2-2.

v. 1965 Spiratella mercinensis (Watelet and Lefèvre, 1880) - Curry, p. 366, figs. 15a-b, 16.

1966 Spirialis mercinensis Watelet and Lefèvre, 1885 - Korobkov, pp. 73, 77, 78.

1967 Valvatina raphistoma - Hucke and Voigt, pp. 99, 104, pl. 45 fig. 1.

1980 Spiratella mercinensis (Watelet and Lefèvre, 1880) - Bristow, Ellison and Wood, p. 266, fig. 3.

1981 Spiratella mercinensis (Watelet and Lefèvre, 1880) - King, pp. 124, 125, 131, figs. 44,45 .

non 1982 Spiratella mercinensis (Watelet and Lefèvre) - Curry, 1982: 36, pl. 1 fig. la-b (= Heliconoides pyrenaica Cahuzac and Janssen, 2010). 


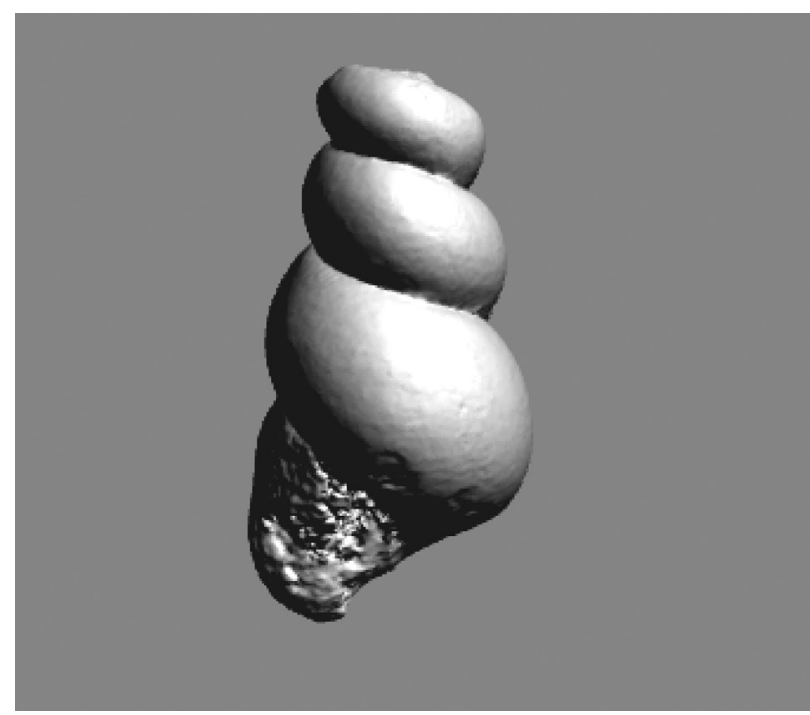

FIGURE 4. Altaspiratella elongatoidea (Aldrich, 1887). Computed tomography (CT) scan of the specimen pictured in Figure 3.3-4, resolution 1.6 micrometer/voxel, $165 \mathrm{kV}$, detector exposure timing $750 \mathrm{~ms}$. For animated version, see online at palaeo-electronica.org/content/ 2016/1662-pteropoda-from-the-usa-petm. By clicking on the image, the interactive $3 \mathrm{D}$ model is activated, and the reader can use the mouse to rotate the specimen and change magnification.

v. 1984 Spiratella mercinensis (Watelet and Lefèvre, 1880) - King, pp. 142, 143, fig. 10.

? 1992 Limacina planidorsalis Hodgkinson - Hodgkinson et al., p. 19, pl. 3 figs. 11-13.

v. 2007 Heliconoides mercinensis (Watelet and Lefèvre) - Janssen et al., p. 163, figs. 7-8 (with extensive synonymy).

v. 2010 Heliconoides mercinensis (Watelet and Lefèvre, 1885) - Janssen, p. 165, fig. 2.

v. 2011 Heliconoides mercinensis (Watelet and Lefèvre, 1885) - Janssen et al., p. 76, figs. 13-16.

v. 2013 Heliconoides mercinensis (Watelet and Lefèvre, 1885) - Janssen et al., p. 29, fig. 9.

Type material. Six syntypes should be present in the Watelet collection, housed in the Musée de Soissons (France), but could not be traced, according to Curry (1965, p. 366).

Type locality. Mercin (Aisne department, France), 'Sables inférieurs' = Sables de Cuise = Montagne de Laon Group, Cuise Formation (Eocene, Ypresian, zone NP 10) (King, 2016, figure 51).

Material examined. Wilson Lake section, NP 9 and NP 10a (Table 1). Bass River section, NP 10a (Table 2), Clayton section, NP 9b and 10a (Table

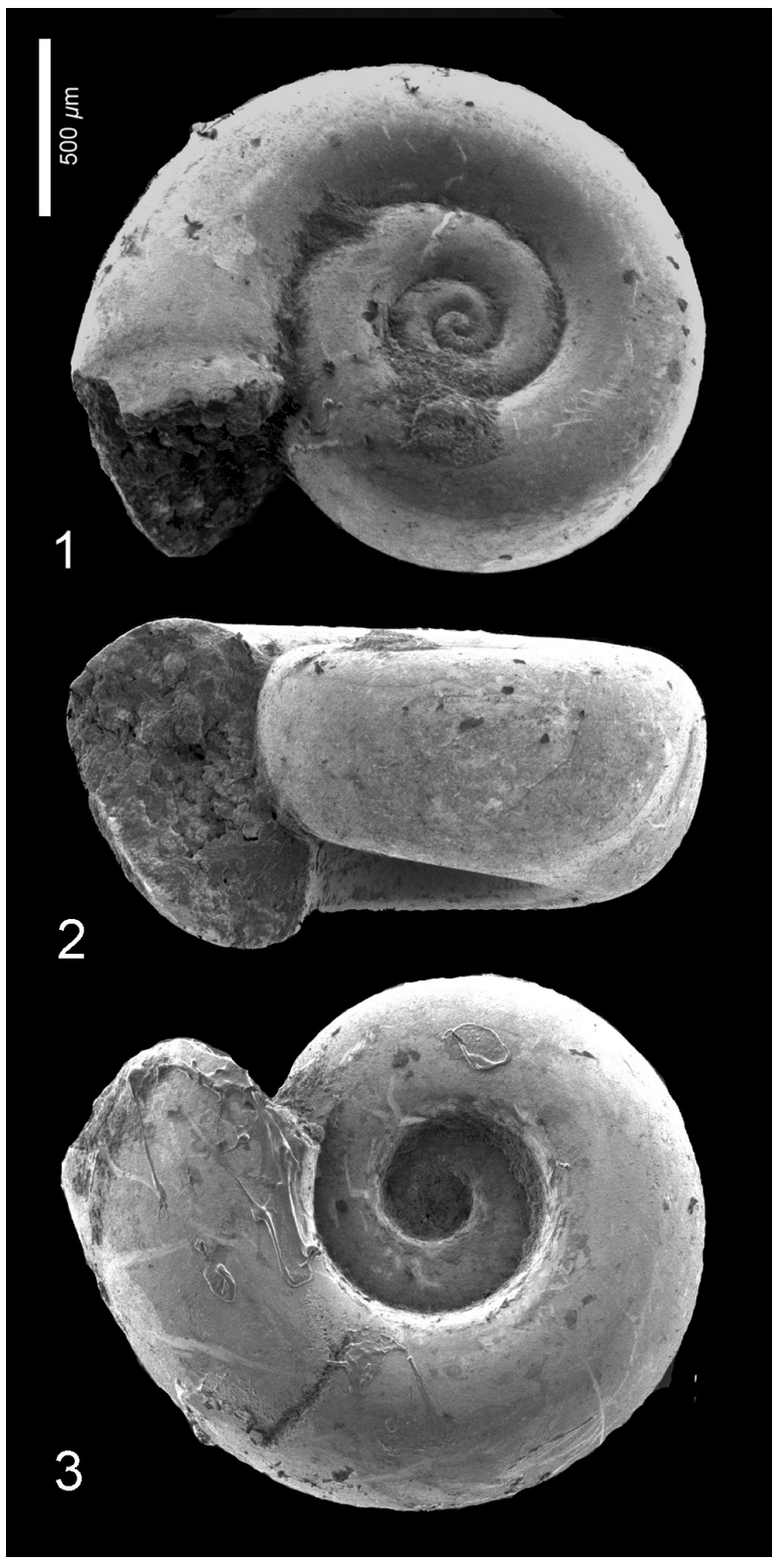

FIGURE 5. Heliconoides mercinensis (Watelet and Lefèvre, 1885). 1-3, Wilson Lake section, sample 27, depth 99.67-99.73 m, RGM 777 223a; 1: apical view, 2: apertural view, 3: umbilical view.

3), Cambridge-Dorchester section, (Table 4). Mattawoman Creek-Billingsley Road section (Table 5). Description. Shell sinistral, almost planispiral, c. two times wider than high when adult, with approximately $3 \frac{1}{2}-3 \frac{3}{4}$ rounded, but in larger specimens laterally somewhat flattened whorls in a regular spiral. Initial whorl hardly or not protruding, apical plane slightly concave or flat. Aperture rounded, with upper margin at the same height or only very slightly lower or higher than penultimate whorl. 


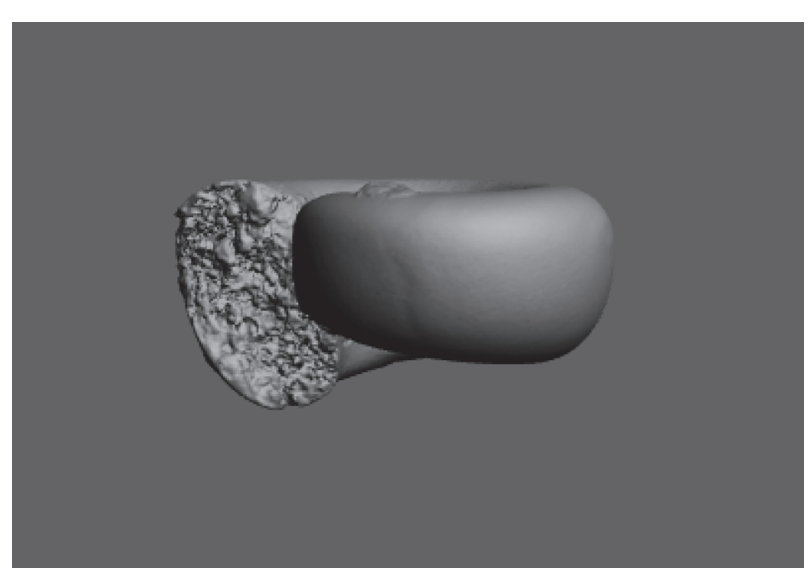

FIGURE 6. Heliconoides mercinensis (Watelet and Lefèvre, 1885). Computed tomography (CT) scan of the specimen pictured in Figure 5.1-3. Resolution 1.9 micrometer/voxel, $165 \mathrm{kV}$, detector exposure timing 750 $\mathrm{ms}$. For animated version, see online at palaeo-electronica.org/content/2016/1662-pteropoda-from-the-usapetm. By clicking on the image, the interactive 3D model is activated, and the reader can use the mouse to rotate the specimen and change magnification.

Basal part of the aperture lowered beyond base of foregoing whorl. Umbilicus wide and deep, occupying c. four tenths of total diameter.

Discussion. The largest available and best preserved specimen, illustrated Figure $5.1(\mathrm{H} 0.84, \mathrm{~W}$ $1.60 \mathrm{~mm}$ ) deviates from the typical form of $H$. mercinensis as described from the Paris Basin 'Cuisian' by a slightly flattened side of the whorls, giving the shell a somewhat rounded trapezoidal shape in frontal view (Figure 5.2). Also, the aperture of this specimen is less circular and more elliptical than in the type, and situated obliquely with respect to the shell's axis. This feature, however, might have been caused by damage on the most abaxial part of the apertural margin. In the same specimen, a further difference is present in a faint indication of a preapertural reinforcement, visible as a weak furrow on the mold just anticipating the margin (Figure 5.1), the result of a preapertural fold or internal thickening. This differs from typical $H$. mercinensis, in which the extreme apertural margin is just slightly widened and v-shaped laterally (see Curry, 1965, figure 16). In spite of these differences, observed in a single specimen only, we consider this to be intraspecific variability for the time being, and final conclusions on identification depend on well-preserved specimens. The same is true for Limacina planidorsalis Hodgkinson in Hodgkinson et al. (1992, p. 18, pl. 3, figure 11-13), the holotype of which has a diameter of $1.0 \mathrm{~mm}$ ), and closely resembles immature $H$. mercinensis. Its indicated stratigraphical range ('early to middle Eocene') coincides with that of $H$. mercinensis.

Although a single, yet unnamed Heliconoides species is currently described (Janssen and Goedert, 2016) from Cretaceous rocks (Campanian), $H$. mercinensis was long considered to be the oldest known pteropod species, with a stratigraphical range starting in the latest Paleocene (Tuscahoma Sand Formation, Bear Creek Marls of Alabama, USA, Zone NP 9; Janssen, 2010) and continuing until the earliest Lutetian. The upper Vincentown Formation in New Jersey is the age equivalent of the Tuscahoma Formation in Alabama (Gibson et al., 1993, 2000). In the southern Salisbury Embayment, the upper portion of the Aquia Formation is age equivalent to the Tuscahoma Formation (Gibson et al., 1993, 2000). In the sections studied here, $H$. mercinensis is the most commonly occurring pteropod species in both NP Zones 9 and 10a, starting immediately above the Paleocene/Eocene boundary, thus slightly younger than the Alabama occurrences.

Distribution. The oldest known occurrence of this species is from the uppermost Paleocene (Tuscahoma Sand Formation, Bear Creek Marls (NP 9 according to Siesser, 1983) of Alabama (USA). This species likely was recorded as Limacina planidorsalis by Hodgkinson et al. (1992) in lower and middle Eocene cuttings of boreholes offshore eastern Canada. Apart from several occurrences in the Cuise Formation of the Paris Basin (see Curry, 1965) and the Ypresian Middle Blue Marl Formation of Pradelle-en-Val (Aude, France; Pirkenseer et al., 2013), this species is known in Europe from the Ypresian of Denmark (Fur Formation, Mo Clay Member and Lillebælt Formation), from the Ypresian (London Clay Formation) in southern England, the Ypresian (Panisel and Flanders formations) in Belgium, and from contemporaneous rocks in the Netherlands (Opende borehole, Rotterdam E55 borehole). Finally, the species was recorded from the Alai Formation, Uzbekistan (Ypresian, Eocene, NP 13; Janssen et al., 2011) and an unnamed formation at the Ypresian/Lutetian transition in the Soh Area (Isfahan, Iran; Janssen et al., 2013). Most of these occurrences are documented in the Naturalis collection with c. 175 specimen lots. Curiously, this species is absent from the very rich pteropod assemblage of Gan, SW France; Ypresian, NP 12-13. 


\section{Genus LIMACINA Bosc, 1817}

Type species. Clio helicina Phipps, 1774 by monotypy $($ Recent $)=$ Limacina helicina (Phipps, 1774).

Limacina aegis Hodgkinson in Hodgkinson, Garvie and Bé, 1992

Figures 7.1-11, 8

*1992 Limacina aegis Hodgkinson, in Hodgkinson et al., p. 15, pl. 1, figs. 10-15.

2013 Limacina aegis Hodgkinson; Janssen et al., p. 31.

Type material. Holotype USNM 180485, paratype USNM 180486 and 5 additional specimens.

Type locality. Amoco-Imperialis \#A-1 Gannet O-54

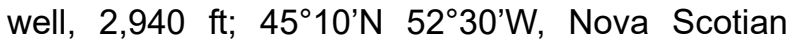
shelf, offhore eastern Canada (early Eocene).

Description. See Hodgkinson, in Hodgkinson et al. (1992).

Discussion. Limacina aegis, characterized by its depressed, lenticular shell (apical angle c. $133^{\circ}$ ) with a distinctly carinated periphery, seems to be related to Limacina yasdii Janssen, in Janssen et al., 2013 (p. 31, figures 13-14), introduced from an unnamed unit of latest Ypresian to earliest Lutetian age in the Soh area, Isfahan province, Iran. That species differs from the present one in being relative higher with somewhat more convex, less strongly carinated whorls and a much narrower umbilicus.

Material examined. Wilson Lake section, NP 9 and 10a (Table 1), Bass River section, NP 10a (Table 2), Clayton section, NP 9b and 10a (Table 3), Cambridge-Dorchester section (Table 4).

Distribution. Limacina aegis thus far was only known by its type material, the age of which could only roughly be indicated as 'early Eocene? NP1013 ' because of downhole contamination (Hodgkinson et al., 1992). In the present material, this species is already present in the lowermost sample (NP 9) of the cored (and therefore contaminationfree) Wilson Lake section, and continues through zones NP 9 and NP 10a. Together with Altaspiratella elongatoidea, Limacina aegis appears 7.61 ky (Table 1) after the onset of the CIE, and therefore is one of the oldest known pteropods, with the exception of a single Campanian unnamed Heliconoides specimen (Janssen and Goedert, 2016) and Heliconoides mercinensis, which first appeared in the late Paleocene (Janssen, 2010). The equally related species $L$. helicos Hodgkinson, in Hodgkinson et al. (1992, p. 17, pl. 3, figures 1-5), differing from $L$. aegis by a much higher shell with an apical angle of just $63^{\circ}$ and completely flat whorls, is only known by its type specimens and was said to occur during the NP 10 and NP 11 zones.

Limacina novacaesarea Janssen and Sessa sp. nov.

Figures 9.1-7, 10

zoobank.org/A893D78B-B268-443C-8585-A9189A97997F

Holotype. RGM 777 219, Figure 9.1-3 (H 1.10, W $1.32 \mathrm{~mm}$ ). A CT-scan of this specimen is available in Figure 10.

Type locality. Wilson Lake (Gloucester County, New Jersey, U.S.A.), cored borehole of United States Geological Survey (USGS), coordinates N39³9'21", W7502'31", drilled 2000, sample 24, depth 98.76-98.82 m.

Stratigraphy. Marlboro Clay (Eocene, Ypresian), 59.14 ky after PETM, nannoplankton zone 10a.

Paratypes. Wilson Lake sample 22 (1 specimen, Figure 9.4-6; RGM 777 215a and 1 juvenile specimen, RGM 777 215; and sample 27 (1 specimen; Figure 9.7, RGM 777 225) (Table 1).

Additional specimens. Bass River section sample 18 (1 specimen ?), RGM 777297 (specimen lost); Clayton section sample 14 (1 specimen, RGM 777 314 (Table 2).

Etymology. Nova Caesarea is the Latin name for New Jersey. Limacina gender feminine.

Diagnosis. Limacinid with conical shell, slightly wider than high, of $3 \frac{3}{4}$ rounded whorls, initial whorl planispiral and slightly sunken, umbilicus very wide and deep, occupying almost four tenths of shell diameter.

Description. Shell of rounded conical shape, 1.2 times wider than high, of $3 \frac{3}{4}$ convex whorls, gradually increasing in diameter, attaching at mid-height of preceding whorl. Initial whorl planispiral and somewhat lowered (Figure 9.6), giving the shell a flattened apex in frontal view. Last whorl large, occupying 9/10th of total shell height, regularly rounded at periphery. Aperture large, occupying three quarters of total shell height, elliptical, pointed above, regularly rounded below and with a straight columellar part. Apertural margin simple in available specimens. Base of shell with very large and deep umbilicus occupying $38 \%$ of shell diameter (holotype).

Discussion. Limacina novacaesarea resembles $L$. perforata Janssen, in Janssen et al. (2013, p. 30, figure 12) from unnamed rocks of latest Ypresian to earliest Lutetian age in the Soh Area, Iran. That species reaches considerably larger dimensions $(\mathrm{W}=2.4 \mathrm{~mm}$ ) but has the same number of whorls, has a lower apical shell part the apex of which is not planispiral, its whorls attach much higher on the preceding one, and its umbilicus is narrower (about 


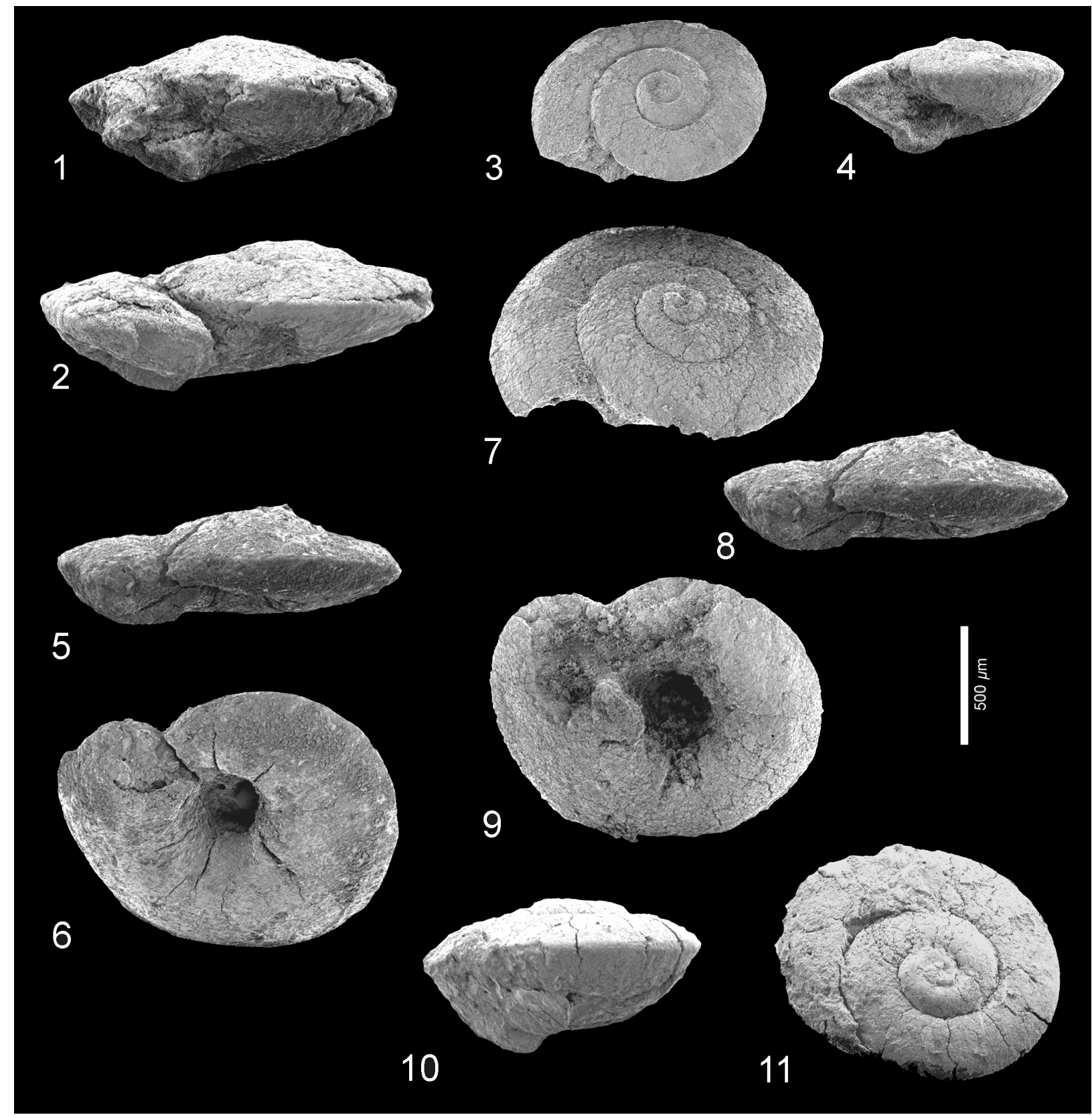

FIGURE 7. Limacina aegis Hodgkinson in Hodgkinson, Garvie and Bé, 1992. 1, Clayton section, sample 19, depth 94.55-94.58 m, RGM 777319a; apertural view. 2, Clayton section, sample 21, depth 95.07-95.10 m, RGM 777 323; apertural view. 3-4, Wilson Lake section, sample 34, depth 101.80-101.86 m, RGM 777 236a; 3: apical view, 4: apertural view. 5-6, Wilson Lake section, sample 52, depth 07.08-107.11 m, RGM 777 264a; 5: apertural view, 6: umbilical view. 7-9, Wilson Lake section, sample 63, depth 108.20-108.26 m, RGM 777283 (specimen lost); 7: apical view, 8: apertural view; 9: umbilical view. 10-11, Cambridge-Dorchester section, sample 15, depth 220.22-220.28 m, RGM 777 338; 10: apical view, 11: apertural view.

$20 \%$ of shell diameter) with a faint ridge bordering the shell's basal plane. Finally, in L. perforata the columellar part of the apertural margin has a clear abaxial curvature, not seen in L. novacaesarea.
Distribution. The new species is only known from the localities specified above.

Limacina sp. 1

Figures 11.1-6, 12 


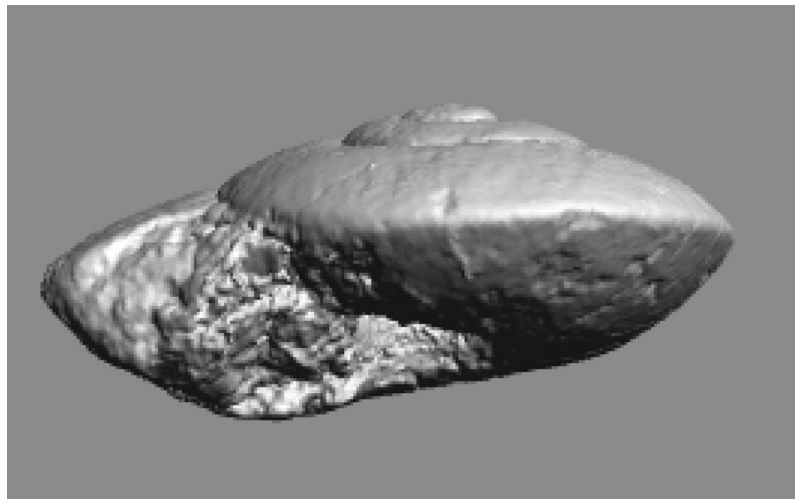

FIGURE 8. Limacina aegis Hodgkinson in Hodgkinson, Garvie and Bé, 1992. Computed tomography (CT) scan of specimen RGM 777.264b, which has the same locality data as the specimen in Figure 7.5-6. Resolution 2.0 micrometer/voxel, $165 \mathrm{kV}$, detector exposure timing $750 \mathrm{~ms}$. For animated version, see online at palaeo-electronica.org/content/2016/1662-pteropodafrom-the-usa-petm. By clicking on the image, the interactive $3 \mathrm{D}$ model is activated, and the reader can use the mouse to rotate the specimen and change magnification.

Description. The few available specimens differ from Heliconoides mercinensis, as described above, by their planorboid shape with a somewhat lower height/width-ratio and a completely flat apical plane. Their whorls increase somewhat slower in diameter, but specimens of the same size as in $H$. mercinensis have the same number of whorls. The lower margin of the aperture reaches barely beyond the base of the penultimate whorl and the umbilicus is wider. In front view, the shape is similarly trapezoidal, but more depressed.

Material examined. Wilson Lake section, NP 9 and 10a (Table 1); Cambridge-Dorchester section (Table 4).

Discussion. We are hesitant to describe the present specimens as representing a new species, considering the close resemblance to $H$. mercinensis and its observed variability, as well as the poor preservation of all specimens, and thus we think it better to record this form in open nomenclature. As no indication of a reinforced apertural margin is present in these specimens, we include this species in the genus Limacina. These points of view may be reconsidered when better-preserved material becomes available.

Distribution. Only known from the specimens here recorded.

Limacina sp. 2

Figure 13.1-2
Description. A single specimen $(\mathrm{H} 0.54$, W 0.90 $\mathrm{mm}$ ) in poor preservation of $\mathrm{c}$. three whorls, resembles juvenile Heliconoides mercinensis, but is relatively higher and has a perfectly rounded whorl shape. It has a slightly raised apical shell part. Its umbilicus is very small, occupying only one tenth of the shell diameter.

Material examined. Cambridge-Dorchester section (Table 4) (1 specimen, Figure 13.1-2; RGM 777 345).

Discussion. This specimen does not align with any of the known limacinid species, and there is no sign of apertural reinforcements. The species Heliconoides texana (Garvie and Hodgkinson, in Hodgkinson et al., 1992, p. 20, pl. 4, figures 3-6) and Limacina wechesensis Hodgkinson, in Hodgkinson et al., 1992, p. 21, pl. 5, figures 1-7, pl. 6, figures 14) roughly have a similar shape but seem to differ in proportions. Considering the poor condition of our specimen we prefer to only identify it in open nomenclature. More and better-preserved specimens are needed for a final interpretation. Because of its fragility, this specimen was not subjected to CT scanning.

Distribution. Currently only known by the specimen described here.

\section{DISCUSSION}

Pteropods from the Paleocene-Eocene Thermal Maximum interval (earliest Ypresian) in five boreholes in the northeastern USA Salisbury Embayment are represented by six species, four of which that were identified to species level, and two that have to remain in open nomenclature because of poor preservation. One species is described as new. These six species represent three genera, Altaspiratella, Heliconoides and Limacina. Only the genus Heliconoides was previously known from strata of this age and older. A single unnamed specimen of Heliconoides was recently discovered from the Campanian of the San Juan Islands, Washington, USA (Janssen and Goedert, 2016), and the species $H$. mercinensis was recorded from the uppermost Paleocene of Alabama (Janssen, 2010). In our studied assemblages from the Atlantic Coastal Plain, H. mercinensis is the most common species from the earliest Eocene (Ypresian) onward. Although some morphological features of these specimens seem to differ from the typical form of $H$. mercinensis, as described from the Ypresian of the Paris Basin, their generally poor preservation prevents the sufficient evaluation of these differences, and thus they currently are considered intraspecific variability. Abundantly occur- 


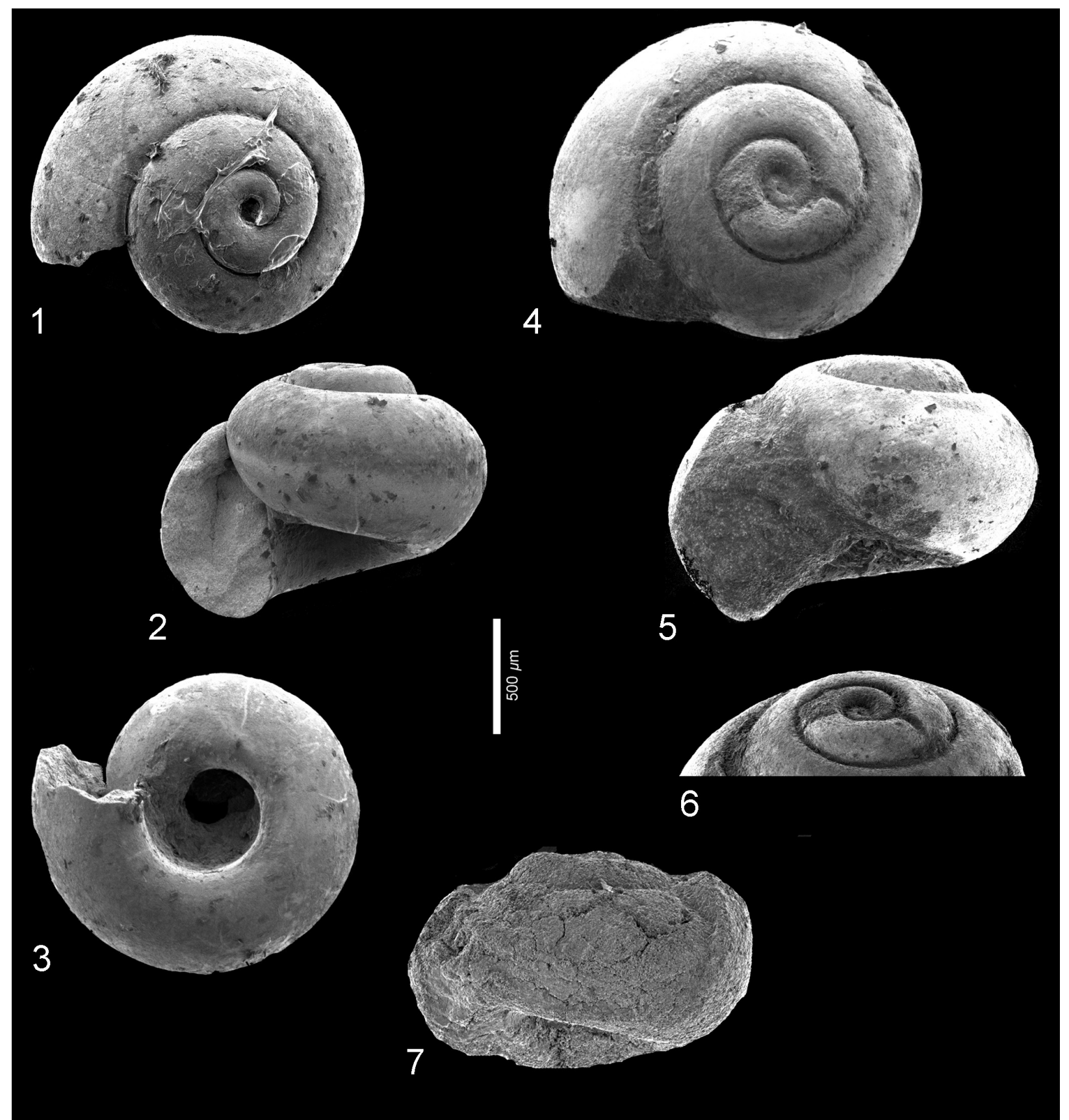

FIGURE 9. Limacina novacaesarea Janssen and Sessa sp. nov. 1-3, Holotype, Wilson Lake section, sample 24, depth 98.76-98.82 m, RGM 777 219; 1: apical; view, 2: apertural view, 3: umbilical view. 4-6, Paratype 1, Wilson Lake section, sample 22. Depth 98.15-98.21 m, RGM 777 215a; 4: apical view, 5: apertural view, 6: oblique apical view to show lowering of initial whorl. 7, Paratype 2, Wilson Lake section, sample 27, depth 99.67-99.73 m, RGM 777 225; apertural view of poorly preserved, slightly depressed specimen.

ring specimens from the Danish Fur Formation (Janssen and Peijnenburg, 2013, figure 19.7) or the London Clay Formation in England, which may be coeval to, or slightly younger than, our samples, usually are preserved as internal calcitic molds that cannot be isolated from very hard concretions and are therefore difficult to compare.

The studied pteropods were recovered from sediments probably deposited at depths ranging from inner shelf in the southern Salisbury Embayment through middle-outer shelf depths in the 


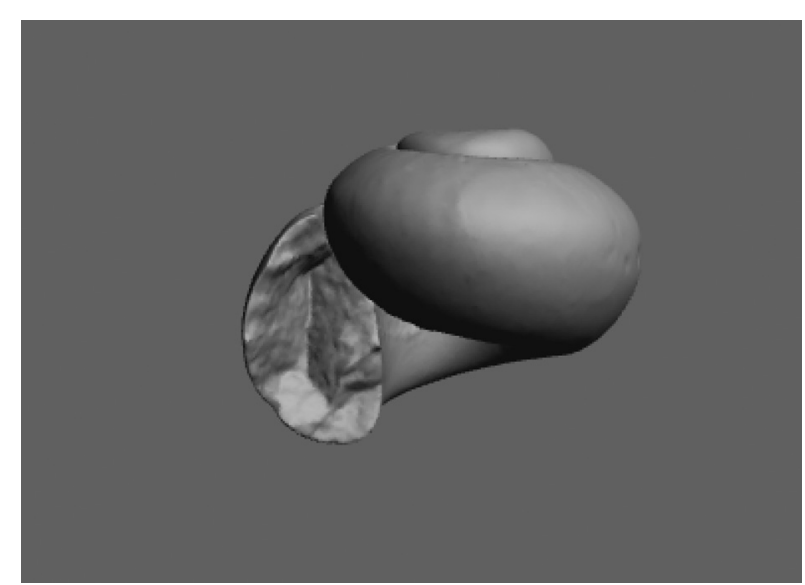

FIGURE 10. Limacina novacaesarea Janssen and Sessa sp. nov. Computed tomography (CT) scan of the specimen pictured in Figure 9.1-3. Resolution 4.0 micrometer/voxel, $185 \mathrm{kV}$, detector exposure timing 750 $\mathrm{ms}$. For animated version, see online at palaeo-electronica.org/content/2016/1662-pteropoda-from-the-usapetm. By clicking on the image, the interactive 3D model is activated, and the reader can use the mouse to rotate the specimen and change magnification.

northern Salisbury Embayment - New Jersey Coastal Plain ( 100-150 m; Stassen et al., 2014, 2015). At the deepest New Jersey site, Bass River, the $\mathrm{pH}$ in surface waters (as indicated by $\mathrm{B} / \mathrm{Ca}$ measured on several species of planktic foraminifera, which overlap in habitat depth with pteropods) may have declined by 0.3-0.4 units during the PETM (Babila et al., 2016), in the same sediments where the pteropods are preserved (Figure 14). The $\mathrm{pH}$ declined to a similar extent in open ocean locations in the Atlantic and Pacific Oceans (Penman et al., 2014).

Experiments with wild and incubated, and living and dead, pteropods indicate that shell dissolution occurs near the level of aragonite saturation, and that the effects of dissolution are evident in as little as 4 to 14 days (see discussion in Bednaršek et al., 2012b). Therefore, lower carbonate saturation would be expected to prevent the thin-walled pteropod shells from being preserved, although there is some disagreement on the ease of dissolution (Peck et al., 2016). Pteropod specimens in the studied samples are nearly all preserved as pyritic internal molds, which indicate that the shells reached the sea bottom, became buried in the sediment, and subsequently fossilized. Apparently, the drop in surface water $\mathrm{pH}$ during the PETM in the Salisbury Embayment (or outside the embayment in open ocean) was not enough to dissolve pteropod shells before or directly after they reached the seafloor, because dissolution of the shells must have taken place following pyritization. Babila et al. (2016) argue that local coastal waters were rapidly buffered (with a slight increase in $\mathrm{B} / \mathrm{Ca}$ at about the level where pteropods first appear; Figure 14), in agreement with the observation that shelf calcareous benthic foraminifera did not suffer severe extinction (Stassen et al., 2012a, 2014). This less severe extinction in shelf waters contrasts with that of deeper water benthic species (Thomas, 1998, 2007). The MCBR2 core is the most proximal (Figure 1) of the studied cores, and the only one to preserve shell material, in support of the buffering argument (Babila et al., 2016), especially when considering that this core is the least likely to contain pteropods because they are farthest from their living habitat. Living pteropod assemblages predominantly inhabit water depths of $200 \mathrm{~m}$ or more, and there is no reason to suppose that this was different during the early Eocene. Their occurrence in shallower environments, such as those represented by the New Jersey core sections, may be explained through transport from more open waters by coastal currents, as has been documented for both modern and fossil pteropod deposits (e.g., Herman and Rosenberg, 1969; Singh and Singh, 2010). Mass strandings of recent pteropods on beaches are known from the Mediterranean and the Red Sea. A well-known fossil example is the frequent occurrence of Vaginella depressa Daudin, 1800, in shallow water sediments of the lower Miocene in the Aquitaine Basin, SW France (Cahuzac and Janssen, 2010). Garvie (1996) recorded common pteropods from the Ypresian Reklaw Formation of Texas, with an estimated paleo-depth of 30-90 m. All of these may be explained by transport by coastal currents.

We do not know whether the apparently sudden appearance of three pteropod genera in the sediment record indicates evolution, a change in the coastal current systems, or better preservation. The underlying Vincentown Formation, as well as the overlying parts of the Manasquan Formation, show much worse preservation of benthic foraminifera than the Marlboro Clay, and planktic foraminifera (which are more sensitive to dissolution than benthic foraminifera) are rare or absent in most of the Vincentown Formation (e.g., Gibson et al., 1993, 2000; Stassen et al., 2012c, 2014). The sedimentation rates for the Marlboro Clay, deposited during the PETM, were much higher than for the underlying and overlying formations (Olsson and Wise, 1987; Gibson et al., 2000: John et al., 2008; Stassen et al., 2012c), possibly due to an intensifi- 


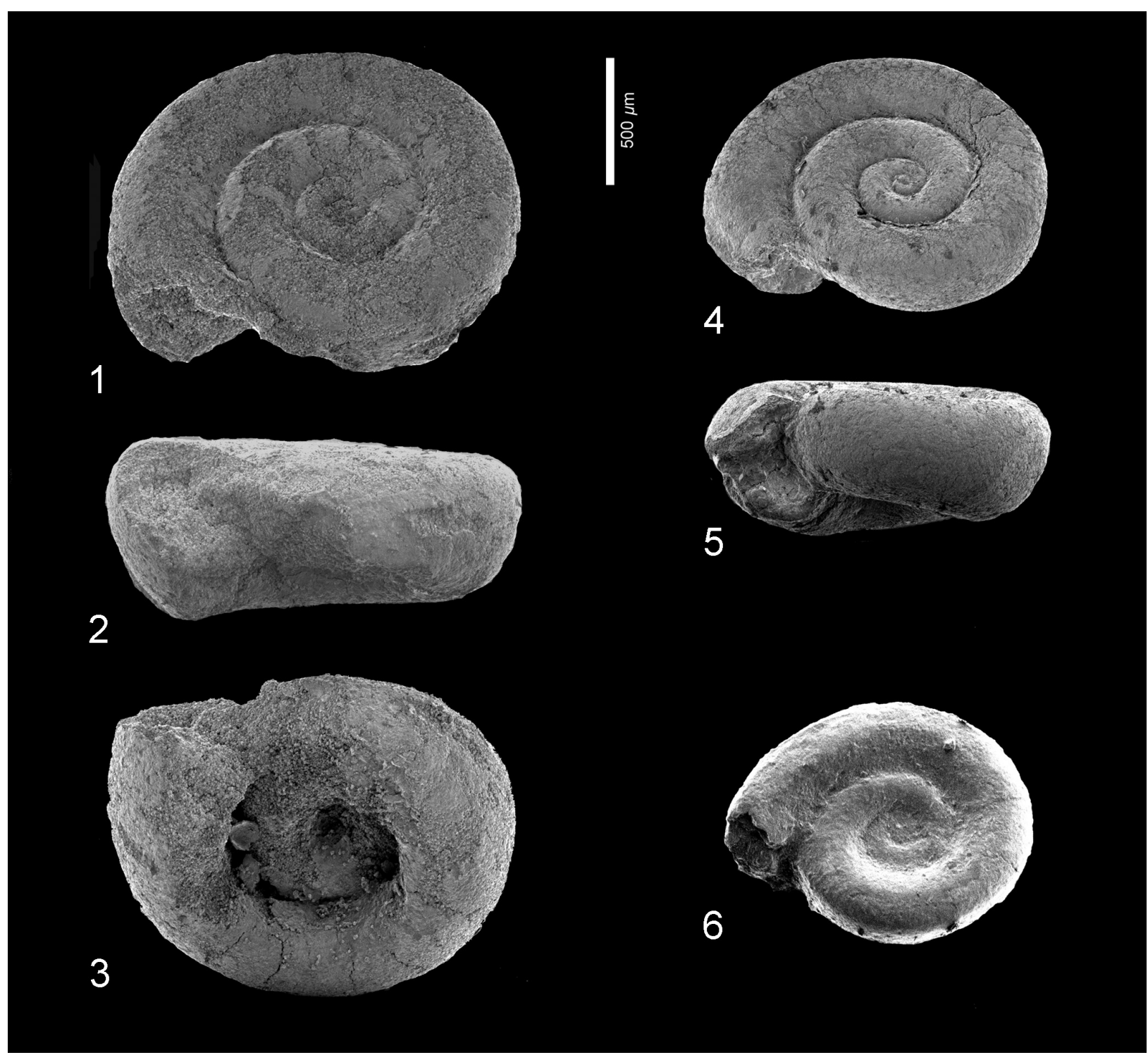

FIGURE 11. Limacina sp. 1. 1-3, Wilson Lake section, sample 37, depth 102.72-102.78 m, RGM 777 241; 1: apical view, 2: apertural view, 3: umbilical view. 4-5, Wilson Lake section, sample 50, depth 106.68-106.74 m, RGM 777259a; 4: apical view, 5: apertural view. 6, Wilson Lake section, sample 40, depth 103.02-103.08 m, RGM 777248; apical view.

cation of the hydrological cycle during the warm PETM, with increased transport of silts and clays to the coastal regions (Gibson et al., 1994; Kopp et al., 2009). The rapid burial of the pteropod shells in the clayey material undoubtedly facilitated their preservation. Warm bottom waters during the PETM could have further enhanced their preservation. It therefore is possible that pteropods existed during the time of deposition of the Vincentown and Aquia Formations (late Paleocene), but were not preserved. Such potentially existing ancestors, however, have not been found anywhere else, and an alternate hypothesis is that pteropods, like gymnodont fish, planktic foraminifera, and land vertebrates, diversified during the Paleocene Eocene Thermal Maximum (Kelly et al., 1996; Bralower, 2002; Gibbs et al., 2006a, 2006b; Schneider et al., 2013; Bannikov et al., 2016). Changes in environmental conditions that may have influenced this diversification include increased seawater temperature, decreased oxygenation, changes in nutrient partitioning resulting in more eutrophic shelf and more oligotrophic open ocean conditions, and carbonate undersaturation (e.g., Sluijs et al., 2007; 


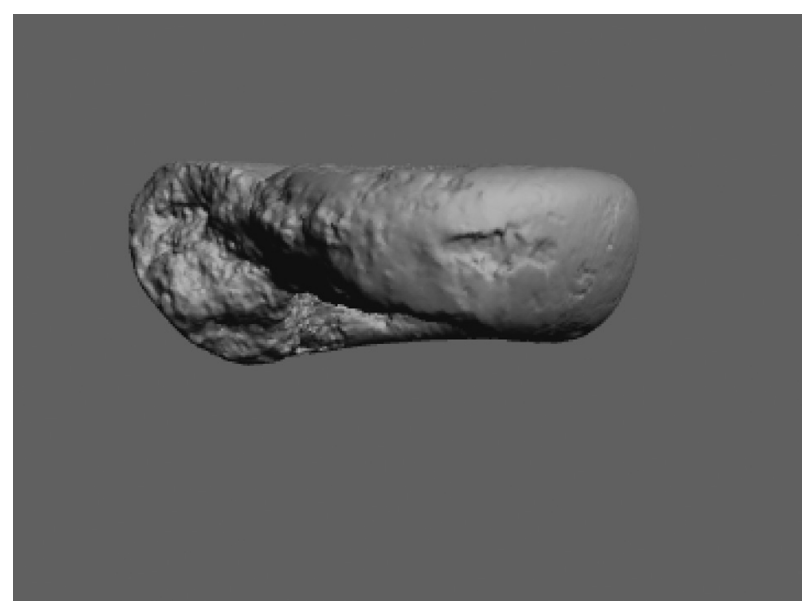

FIGURE 12. Limacina sp. 1. Computed tomography (CT) scan of the specimen pictured in Figure 11.1-3. Resolution 4.9 micrometer/voxel, $145 \mathrm{kV}$, detector exposure timing $750 \mathrm{~ms}$. For animated version, see online at palaeo-electronica.org/content/2016/1662pteropoda-from-the-usa-petm. By clicking on the image, the interactive $3 \mathrm{D}$ model is activated, and the reader can use the mouse to rotate the specimen and change magnification.
Mclnerney and Wing, 2011; Winguth et al., 2012; Sluijs et al., 2014; Penman et al., 2014). The diversification of the aragonitic pteropods at this time might be seen as surprising because of the documented ocean acidification of upper ocean waters, but possibly the increased nutrient levels (Sluijs and Brinkhuis, 2009; Stassen et al., 2015) and/or higher temperatures may have been a causal factor, in view of the observation that there is a positive correlation between pteropod species numbers and paleotemperature for the Mediterranean Basin (Janssen and Peijnenburg, 2013; p. 350, figures 19-10).

\section{CONCLUSIONS}

We document for the first time that pteropods, like other pelagic organisms, were affected by the environmental changes during the PETM (earliest Ypresian), and that global warming and its associated environmental effects may have influenced speciation in pteropods. Six species belonging to three genera are present within 10,000 years after the onset of the PETM in the Salisbury Embayment

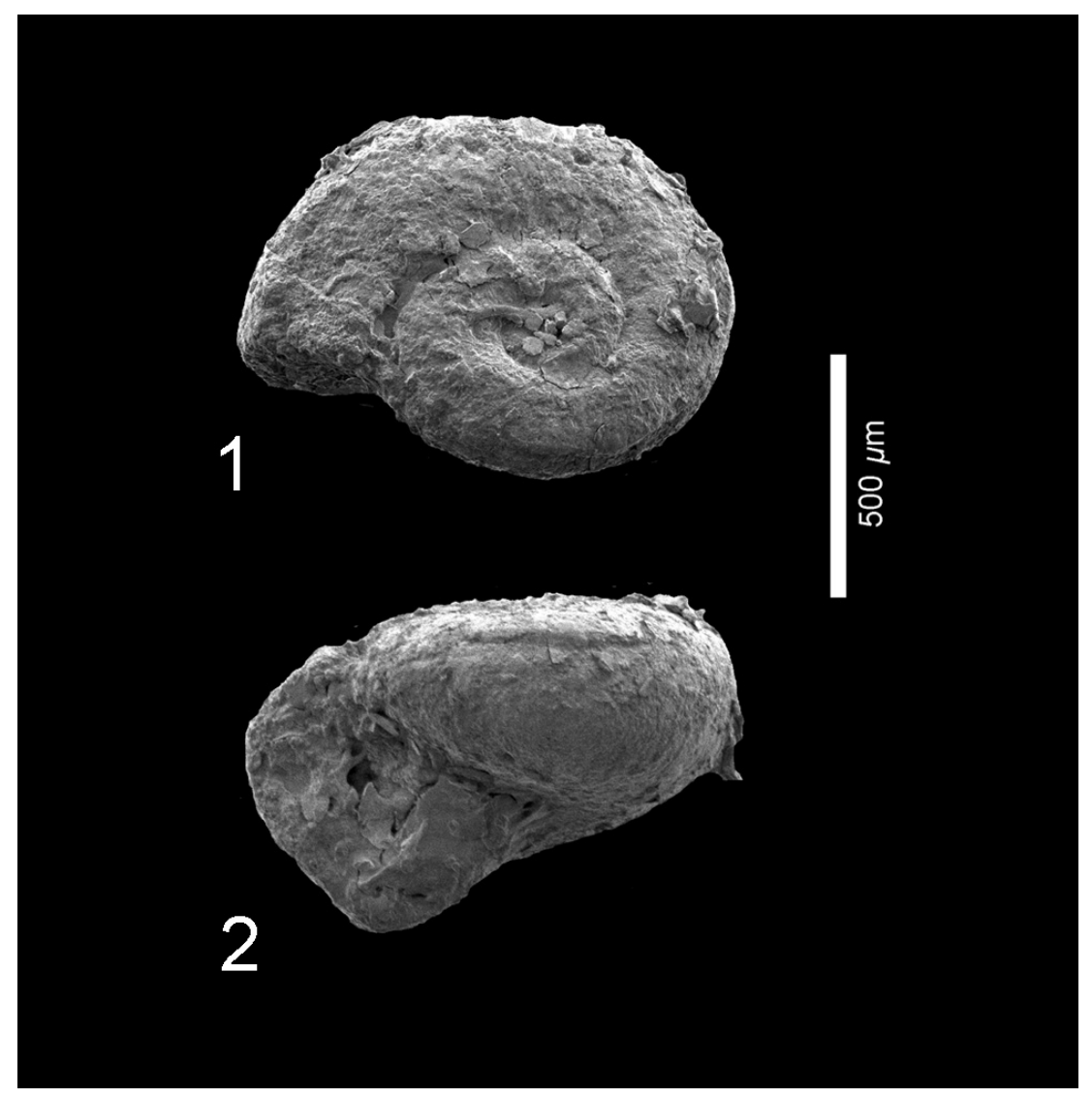

FIGURE 13. Limacina sp. 2. 1-2, Cambridge-Dorchester section, sample 26, depth 222.61-222.62 m, RGM 777 345; 1: apical view, 2: apertural view. 


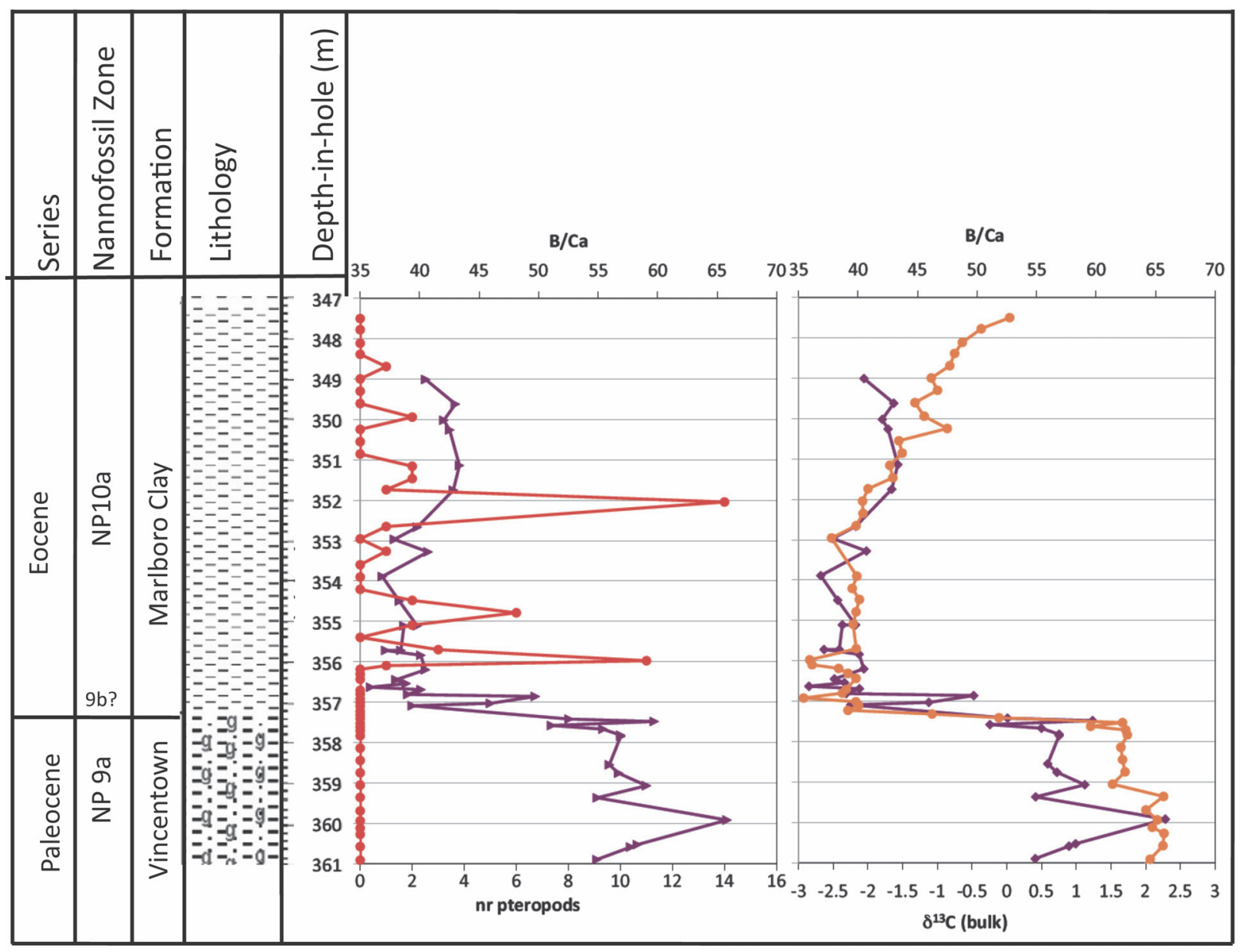

FIGURE 14. Stratigraphy and lithology for the Bass River core, after Stassen et al., 2015. The number of pteropods recognized (red) is compared to the $\mathrm{B} / \mathrm{Ca}$ values (purple) in the planktonic foraminiferal genus Acarinina, a surfacewater (mixed layer) dweller (Babila et al., 2016), and with $\delta^{13} \mathrm{C}$ values of bulk carbonate (orange), indicating the location of the carbon isotope excursion (Stassen et al., 2015). The change in $\mathrm{B} / \mathrm{Ca}$ is interpreted as reflecting a decline in $\mathrm{pH}$ by $\sim 0.3-0.4 \mathrm{pH}$ units (Babila et al., 2016). The irregularity of pteropod distribution is likely because they were transported to these sites, and do not represent an in situ population.

of the Atlantic Coastal Plain (in our age model), whereas just one genus, with a single described species, was known previously, from the uppermost Paleocene of Alabama and Denmark. Hodgkinson et al. (1992, text-figure 3) listed six pteropod species for Zone NP 10, only two of which are represented in our material, so we conclude that the tendency of increasing species numbers with time continued during the later Ypresian. Curry (1982) and Cahuzac and Janssen (2010) listed 14 pteropod species from latest NP 12 to earliest NP 13, most of which belong to the Limacinioidea, but also include some Cavolinioidea (Camptoceratops, Euchilotheca), a group not represented in the present material. Cavolinioidea species are supposed to have developed from early limacinids (Janssen and Peijnenburg, 2013, figure 19.8) by despiralisation, of which the here recorded species Altaspiratella elongatoidea may represent the earliest indication. In terms of pteropod biostratigraphy, the assemblages described herein belong to Pteropod Zone 6 (Janssen and King, 1988), from which previously only the species Heliconoides mercinensis was known.

\section{ACKNOWLEDGMENTS}

J.M. Self-Trail and M.M. Robinson (Eastern Geology and Paleoclimate Science Center, US Geological Survey Reston, Virginia, USA) provided the sediment samples and pteropod specimens from the Mattawoman Creek-Billingsley Road and Cambridge-Dorchester sections. R.L. Oakes 
(Department of Geosciences, Pennsylvania State University) is thanked for assistance in picking specimens from the Cambridge-Dorchester core, as are W.E. Spivey (Eastern Geology and Paleoclimate Science Center, US Geological Survey Reston, Virginia, USA) for processing, and M.M. Robinson for picking, the Mattawoman Creek-Billingsley Road core. We thank R. Helwerda (Naturalis Biodiversity Center, Leiden, NL) for making the SEM-images and R. Pouwer of the same institute for making the photograph of Figure 2. We are grateful for the assistance of $\mathrm{M}$. Hill and $\mathrm{H}$. Towbin (Microscopy and Imaging Facility at the American Museum of Natural History), and the AMNH Masters of Arts in Teaching 2015 graduates S. Drotzer, M. Fichman, G. Salwen, and J. Sharoff in CT scanning and reconstruction. M.M. Robinson provided thoughtful comments on a draft of this paper. JAS was supported by a Katherine Davis Postdoctoral Fellowship at the AMNH and USA National Science Foundation Grant NSF-DR K-12:11119444. ET was in part supported by USA National Science Foundation Grant NSF OCE 1232413. Two anonymous reviewers are thanked for their constructive critical reading of the manuscript and useful comments.

\section{REFERENCES}

Aldrich, T.H. 1887. Notes on Tertiary fossils, with descriptions of new species. The Journal of the Cincinnati Society of Natural History, 10(2):78-83.

Aldrich, T.H. 1895. New or little known Tertiary Mollusca from Alabama and Texas. Bulletins of American Paleontology, 1:55-83.

Aubry, M.-P., Cramer, B.S., Miller, K.G., Wright, J.D., Kent, D.V., and Olsson, R.K. 2000. Late Paleocene event chronology: unconformities, not diachrony. Bulletin de la Société Géologique de France, 171:367378.

Aubry, M.-P., Ouda, K., Dupuis, C., Berggren, W.A., Van Couvering, J.A., and the Members of the Working Group on the Paleocene/Eocene Boundary. 2007. The Global Standard Stratotype-section and Point (GSSP) for the base of the Eocene Series in the Dababiya section (Egypt). Episodes, 304:271-286.

Babila, T., Rosenthal, Y., Wright, J.D., and Miller, K.G. 2016. A continental shelf perspective of ocean acidification and temperature evolution during the Paleocene-Eocene Thermal maximum. Geology, 44:75278. Online edition. Doi:10.1130/G37522.1.

Bannikov, A.F., Tyler, J.C., Arcila, D., and Carnevale, G. 2016. A new family of gymnodont fish (Tetraodentiformes) from the earliest Eocene of the Peri-Tethys (Kabardino-Balkaria, northern Caucasus, Russia). Journal of Systematic Paleontology Online edit doi:10.1080/14772019.2016.1149115.
Bednaršek, N., Možina, J., Vogt, M., O’Brien, C., and Tarling, G A. 2012a. The global distribution of pteropods and their contribution to carbonate and carbon biomass in the modern ocean. Earth System Science Data, 1:1-20. Doi:10.5194/essd-1-1-2012.

Bednaršek, N., Tarling, G.A., Bakker, D.C.E., Fielding, S., Jones, E.M., and Venables, H.J. 2012b. Extensive dissolution of live pteropods in the Southern ocean. Nature Geoscience 5:881-885. doi: $10.1038 /$ ngeo1635.

Bednaršek, N. and Ohman, M.D. 2015. Changes in pteropod distributions and shell dissolution across a frontal system in the California Current System. Marine Ecology Progress Series, 523:93-103. Doi: 10.3354/meps11199.

Bosc, L.A.G. 1817. Limacine. Nouveau Dictionnaire d'Histoire naturelle, 18:42. (In French)

Bouchet, P. and Rocroi, J.P. 2005. Classification and nomenclator of gastropod families. Malacologia 47:1397.

Bralower, T.J. 2002. Evidence of surface water oligotrophy during the Paleocene-Eocene thermal maximum: Nannofossil assemblage data from Ocean Drilling Site 690, Maud Rise, Weddell Sea. Paleoceanography, 17:13-1-13-12.

Bristow, C.R., Ellison, R.A., and Wood, C.J. 1980. The Claygate Beds of Essex. Proceedings of the Geologists' Association, 91:261-277.

Burmeister, H. 1837. Handbuch der Naturgeschichte zum Gebrauch bei Vorlesungen; zweite Abtheilung. Zoologie. T.C.F. Enslin, Berlin. (In German)

Cahuzac, B. and Janssen, A.W. 2010. Eocene to Miocene holoplanktonic Mollusca (Gastropoda) of the Aquitaine Basin, southwest France. Scripta Geologica, 141:1-193.

Collins, R.L. 1934. A monograph of the American Tertiary pteropod mollusks. Johns Hopkins University Studies in Geology, 11:137-234.

Cossmann, M. and Pissarro, G. 1910-1913. Iconographie complète des coquilles fossiles de l'Eocène des environs de Paris, 2. Scaphopodes, gastropodes, brachiopodes, céphalopodes \& supplément. Paris. (In French)

Cramer, B.S., Aubry, M.-P., Miller, K.G., Olsson, R.K., Wright, J.D., and Kent, D.V. 1999. An exceptional chronologic, isotopic, and clay mineralogic record of the latest Paleocene thermal maximum, Bass River, NJ, ODP 174AX. Bulletin de la Société Géologique de France, 170:883-897.

Crouch, E.M., Heilmann-Clausen, C., Brinkhuis, H., Morgans, H.E.G., Rogers, K.M., Egger, H., and Schmitz, B. 2001. Global dinoflagellate event associated with the late Paleocene thermal maximum. Geology, 29:315-318.

Curry, D. 1965. The English Palaeogene pteropods. Proceedings of the Malacological Society of London, 36:357-371.

Curry, D. 1982. Ptéropodes éocènes de la tuilerie de Gan (Pyrénées-Atlantiques) et de quelques autres 
localités du SW de la France. Cahiers de Micropaléontologie, 4:35-44.

Cuvier, G. 1795. Second mémoire sur l'organisation et les rapports des animaux à sang blanc, dans lequel on traite de la structure des mollusques et de leur division en ordre, lu à la Société d'Histoire Naturelle de Paris, le 11 prairial an troisième [30 May 1795]. Magazine Encyclopédique, ou Journal des Sciences, des Lettres et des Arts, 1:433-449.

Daudin, F.M. 1800 (an 9 de la République). Nouveau genre de ver à tube calcaire, voisin des serpules et des dentales. Bulletin des Sciences de la Société Philomatique, series (2), No 43:145.

de Blainville, H.M.D. 1824. Mollusques, Mollusca (Malacoz.). Dictionnaire des Sciences naturelles, 32:1392. (In French)

Dickson, A.J., Rees-Owen, R.L., Maerz, C., Coe, A.L., Cohen, A.S., Pancost, R.D., Tayler, K., and Scherbinina, E. 2014, The spread of marine anoxia on the northern Tethys margin during the PaleoceneEocene Thermal Maximum. Paleoceanography, 29:471-488.

Dockery, D.T. III. 1998. Molluscan faunas across the Paleocene/Eocene series boundary in the North American Gulf Coastal Plain, p. 296-322. In Aubry, M.-P., Lucas, S.G., and Berggren, W.A. (eds.), Late Paleocene-early Eocene Climatic and Biotic Events in the Marine and Terrestrial Records. Columbia University Press, New York.

Dollfus, G. and Ramond, G. 1885. Liste des ptéropodes du terrain tertiaire parisien. Mémoires de la Société royale Malacologique de Belgique, 20:38-44. (In French)

d'Orbigny A. 1834-1847. Voyage dans l'Amérique méridionale (le Brésil, la république orientale de l'Uruguay, la république Argentine, la Patagonie, la république du Chili, la république de Bolivia, la république $d u$ Pérou), exécuté pendant les années 1826, 1827, 1828, 1829, 1830, 1831, 1832 et 1833, 5. Bertrand, Paris; Levrault, Strasbourg: xliii + 758 pp. (publication dates of separate issues see Sherborn and Griffin, 1934). (In French)

Dunkley Jones, T., Lunt, D.J., Schmidt, D.N., Ridgwell, A., Sluijs, A., Valdes, P.J., and Maslin, M. 2013. Climate model and proxy data constraints on ocean warming across the Paleocene-Eocene Thermal Maximum. Earth-Science Reviews, 125:123-145.

Dupuis, C., Aubry, M.-P., Steurbaut, E., Berggren, W.A., Ouda, K., Magioncalda, R., Cramer, B.S., Kent, D.V., Speijer, R.P., and Heilmann-Clausen, C. 2003. The Dababiya Quarry section: lithostratigraphy, clay mineralogy, geochemistry and paleontology. Micropaleontology, 49:41-59.

Garvie, C.L. 1996. The molluscan macrofauna of the Reklaw Formation, Marquez Member (Eocene, Lower Claibornian), in Texas. Bulletins of American Paleontology, 111(352):1-177.

Gibbs, S.J., Bown, P.R., Sessa, J.A., Bralower, T.J., and Wilson, P.A. 2006a. Nannoplankton extinction and origination across the Paleocene-Eocene Thermal Maximum. Science, 314(5806):1770-1773.

Gibbs, S.J., Bralower, T.J., Bown, P.R., Zachos, J.C., and Bybell, L.M. 2006b. Shelf and open-ocean calcareous phytoplankton assemblages across the Paleocene-Eocene Thermal Maximum: Implications for global productivity gradients. Geology, 34:233-236.

Gibson, T.G. and Bybell, L.M. 1994. Sedimentary patterns across the Paleocene-Eocene boundary in the Atlantic and Gulf Coastal Plains of the United States. Bulletin de la Société belge de Géologie - Bulletin van de Belgische Vereniging voor Geologie, 103:237-265.

Gibson, T.G., Bybell, L.M., and Mason, D.B. 2000. Stratigraphic and climatic implications of clay mineral changes around the Paleocene/Eocene boundary of the northeastern US margin. Sedimentary Geology, 134:65-92.

Gibson, T.G., Bybell, L.M., and Owens, J.P. 1993. Latest Paleocene lithologic and biotic events in neritic deposits of southwestern New Jersey. Paleoceanography, 8:495-514.

Gray, J.E. 1847. A list of the genera of recent Mollusca, their synonyms and types. Proceedings of the Zoological Society of London, 15(78):129-219.

Gürs, K. and Janssen, A.W. 2004. Sea-level related molluscan plankton events (Gastropoda, Euthecosomata) during the Rupelian (Early Oligocene) of the North Sea Basin. Netherlands Journal of Geosciences, 83:199-208.

Harris, A.D., Miller, K.G., Browning, J.V., Sugarman, P.J., Olsson, R.K., Cramer, B.S., and Wright, J.D. 2010. Integrated stratigraphic studies of Paleocene-lowermost Eocene sequences, New Jersey Coastal Plain: Evidence for glacioeustatic control. Paleoceanography, 25(3): PA3211-PA3228. doi:10.1029/2009PA001800

Harris, G.D. 1899. The Lignitic Stage, 2. Scaphopoda, Gastropoda, Pteropoda and Cephalopoda. Bulletins of American Paleontology, 3(11):3-128.

Herman, Y. 1978. Pteropods, p. 151-159. In Haq, B.U. and Boersma, A. (eds.), Introduction to Marine Micropaleontology. Elsevier, New York.

Herman, Y. and Rosenberg, P.E. 1969. Pteropods as bathymetric indicators. Marine Geology, 7:169-173.

Herrmannsen, A.N. 1846-1852. Indicis generum malacozoorum primordia. Nomina subgenerum, generum, familiarum, tribuum, ordinum, classium: adjectis auctoribus, temporibus, locis systematicis atque literariis, etymus, synonymis. Praetermittuntur Cirripedia, Tunicatae et Rhizopoda, 1 (1846-1847), 2 (1847-1849), supplement (1852). T. Fischer, Cassel. (In Latin)

Hodgkinson, K.A., Garvie, C.L., and Bé, A.W.H. 1992. Eocene euthecosomatous Pteropoda (Gastropoda) of the Gulf and eastern Coasts of North America. Bulletins of American Paleontology, 103(341):5-62.

Hucke, K. and Voigt, E. 1967. Einführung in die Geschiebeforschung. Nederlandse Geologische Vereniging, Zutphen. (In German) 
Janssen, A.W. 1990. Long distance correlation of Cainozoic deposits by means of planktonic gastropods ('pteropods'); some examples of future possibilities. Tertiary Research, 11,65-72.

Janssen, A.W. 2010. Pteropods (Mollusca, Euthecosomata) from the early Eocene of Rotterdam (The Netherlands). Scripta Geologica, Special Issue 7:161-175.

Janssen, A.W. 2012. Systematics and biostratigraphy of holoplanktonic Mollusca from the Oligo-Miocene of the Maltese Archipelago. Bollettino del Museo Regionale di Scienze Naturali, Torino, 28(2):197-601.

Janssen, A.W. and Goedert, J.L. 2016. Notes on the systematics, morphology and biostratigraphy of fossil holoplanktonic Mollusca, 24. First observation of a genuinely Late Mesozoic thecosomatous pteropod. Basteria 80(1-3):59-63.

Janssen, A.W., Jagt, J.W.M., Yazdy, M., Bahrami, A., and Saforeh, S. 2013. Early-middle Eocene faunal assemblages from the Soh area,north-central Iran, 1. Introduction and pteropods (Mollusca, Gastropoda, Thecosomata). Cainozoic Research, 10:23-34. doi: 10.13140/2.1.3210.3044

Janssen, A.W. and King, C. 1988. Planktonic molluscs (Pteropods). In Vinken, R. (ed.). The Northwest European Tertiary Basin. Results of the International Geological Correlation Programme Project no 124. Geologisches Jahrbuch, (A) 100:356-368.

Janssen, A.W., King, C., and Steurbaut, E. 2011. Notes on the systematics, morphology and biostratigraphy of fossil holoplanktonic Mollusca 21. Early and middle Eocene (Ypresian-Lutetian) holoplanktonic Mollusca (Gastropoda) from Uzbekistan. Basteria 75:7193.

Janssen, A.W. and Peijnenburg, K.T.C.A. 2013. Holoplanktonic Mollusca: development in the Mediterranean Basin during the last $30 \mathrm{Ma}$ and their future, $\mathrm{p}$. 341-362. In Goffredo, S. and Dubinsky, Z. (eds.), The Mediterranean Sea. Its History and present Challenges. Springer, Dordrecht. Doi: 10.1007/978-94007-6704-1_19

Janssen, A.W., Schnetler, K.I., and Heilmann-Clausen, C. 2007. Notes on the systematics, morphology and biostratigraphy of fossil holoplanktonic Mollusca 19. Pteropods (Gastropoda, Euthecosomata) from the Eocene Lillebælt Clay Formation (Denmark, Jylland). Basteria 71:157-168.

John, C.M., Banerjee, N.R., Longstaffe, F.J., Sica, C., Law, K.R., and Zachos, J.C. 2012. Clay assemblage and oxygen isotopic constraints on the weathering response to the Paleocene-Eocene thermal maximum, east coast of North America. Geology, 40:591594.

John, C.M., Bohaty, S.M., Zachos, J.C., Sluijs, A., Gibbs, S., Brinkhuis, H., and Bralower, T.J., 2008. North American continental margin records of the Paleocene-Eocene thermal maximum: Implications for global carbon and hydrological cycling. Paleoceanography, 23: PA2217. Doi 10.1029/2007PA001465.
Kelly, D.C., Bralower, T.J., Zachos, J.C., Premoli-Silva, I., and Thomas, E. 1996. Rapid diversification of planktonic foraminifera in the tropical Pacific (ODP Site 865) during the late Paleocene thermal maximum. Geology, 24:423-426.

Kennett, P. and Stott, L.D. 1991. Abrupt deep-sea warming, palaeoceanographic changes and benthic extinctions at the end of the Palaeocene. Nature, 353:225-229. doi:10.1038/353225a0.

King, C. 1981. The stratigraphy of the London Clay. Tertiary Research, Special Paper, 6:1-158.

King, C. 1984. The stratigraphy of the London Clay Formation and Virginia Water Formation in the coastal sections of the Isle of Sheppey (Kent, England). Tertiary Research, 5:121-158.

King. C. 2016. A revised correlation of Tertiary rocks in the British Isles and adjacent areas of NW Europe. Geological Society Special Report, 27:i-iv, 1-719.

King, C., lakovleva, A., Steurbaut, E., Heilmann-Clausen, C., and Ward, D. 2013. The Aktulagay section, west Kazakhstan: a key site for northern mid-latitude early Eocene stratigraphy. Stratigraphy, 10:171-209.

Kopp, R.E., Schumann, D., Raub, T.D., Powars, D.S., Godfrey, L.V., Swanson-Hysell, N.L., Maloof, A.C., and Vali, H. 2009. An Appalachian Amazon? Magnetofossil evidence for the development of a tropical river-like system in the mid-Atlantic United States during the Paleocene-Eocene thermal maximum. Paleoceanography, 24:PA4211. doi: 10.1029/2009PA001783

Korobkov, I.A. 1966. Krylonogie (Mollusca Pteropoda) paleogenovykh otlozhenij juga S.S.S.R. Voprosy Paleontologii, 5:71-92. (In Russian)

Kunz, A. 1996. Schalenmorphologische Merkmale der Ontogenesestadien ausgewählter Pteropoda (Gastropoda: Heterostropha). Hamburg, Unpublished 'Diplom-Arbeit im Studienfach Geologie-Paläontologie an der Universität Hamburg', Germany. (In German)

Linnaeus, C. 1758. Systema naturae per regna tria naturae, secundum classes, ordines, genera, species, cum characteribus, differentiis, synonymis, locis, 1 (editio decima, reformata). Salvii, Holmiae. (In Latin)

Livsey, C. 2015. The planktonic foraminiferal response to the Paleocene-Eocene Thermal Maximum on the Atlantic Coastal Plain. Unpublished Master's Thesis, Pennsylvania State University, University Park, Pennsylvania, USA.

Matthews, S.C. 1973. Notes on open nomenclature and on synonymy lists. Palaeontology, 16:713-719.

Mclnerney, F.A. and Wing, S.L. 2011. The PaleoceneEocene Thermal Maximum: a perturbation of carbon cycle, climate, and biosphere with implications for the future. Annual Review of Earth and Planetary Sciences, 39:489-516.

Meisenheimer J. 1905. Pteropoda. Wissenschaftliche Ergebnisse der Deutschen Tiefsee-Expedition auf 
dem Dampfer "Valdivia" 1898-1899, 9(1):1-314. (In German)

Merle, D. 1986. Contribution à l'étude paléontologique du gisement cuisien de Gan (Pyrénées-Atlantiques): systématique, évolution et paléoécologie, 1-2. Unpublished thesis Ecole Pratique des Hautes Etudes, Dijon, France. (In French)

Miller, K.G., Sugarman, P.J., Browning, J.V., Olsson, R.K., Pekar, S.F., Reilly, T.J., Cramer, B.S., Aubry, M.-P., Lawrence, R.P., Curran, J., Stewart, M., Metzger, J.M., Uptegrove, J., Bukry, D., Burckle, L.H., Wright, J.D., Feigenson, M.D., Brenner, G.J., and Dalton, R.F. 1998. Bass River site. In Miller, K.G., Sugarman, P., and Browning, J.V. (eds.), Proceedings of the Ocean Drilling Program, Initial Reports, 174AX:5-43.

Mörch, O.A.L. 1874. Forsteningerne i Tertiærlagene i Danmark. Beretning om det 11. skandinaviske Naturforskermøde i Kjøbenhavn, 274-298. (In Danish)

Nogan, D.S. 1964. Foraminifera, stratigraphy, and paleoecology of the Aquia Formation of Maryland and Virginia. Cushman Foundation for Foraminiferal Research, Special Volume 7.

Olsson, R.K. and Wise, S.W. 1987. Upper Paleocene to middle Eocene depositional sequences and hiatuses in the New Jersey Atlantic Margin, p. 99-112. In Ross, C.A. and Haman, D. (eds.), Timing and Depositional History of Eustatic Sequences: Constraints on Seismic Stratigraphy. Cushman Foundation for Foraminiferal Research 24, Houston.

Palmer, K.V.W. and Brann, D.C. 1965. Catalogue of the Paleocene and Eocene Mollusca of the southern and eastern United-States, 1. Pelecypoda, Amphineura, Pteropoda, Scaphopoda, and Cephalopoda. Bulletins of American Paleontology, 48(218):1-466.

Peck, V.I., Tarling, G.A., Manno, C., Harper, E.M., and Tynan, E. 2016. Outer organic layer and internal repair mechanism protects pteropod Limacina helicina from ocean acidification. Deep Sea Research II, 127:41-52.

Penman, D.E., Hönisch, B., Zeebe, R.E., Thomas, E., and Zachos, J.C. 2014. Rapid and sustained surface ocean acidification during the Paleocene-Eocene Thermal Maximum. Paleoceanography, 29:57-369. Doi:10.1002/2014PA002621.

Phipps, C.J. 1774. A voyage towards the North Pole undertaken by his Majesty's Command 1773. Bowyer, W. and Nichols, J., London.

Pirkenseer, C.M., Steurbaut, E., Abels, H.A., King, C., and Speijer, R.P. 2013. An expanded lower Eocene shelf sequence from the eastern Aquitaine Basin, SW France: biostratigraphy, biofacies, and stable carbon and oxygen isotopes. Newsletters on Stratigraphy, 46:339-361.

Ravn, J.P.J. 1907. Molluskfaunaen i Jyllands Tertiæraflejringer, en palaeontologisk-stratigrafisk Unders $\varnothing$ gelse. Det Kongelige Danske Videnskabernes Selskabs Skrifter, 7. Naturvidenskabelig og Mathematisk Afdeling, 3:217-384. (In Danish)
Richter, R. 1948 (2nd edition). Einführung in die zoologische Nomenklatur durch Erläuterung der Internationalen Regeln.Waldemar Kramer, Frankfurt. (In German)

Scheibner, C. and Speijer, R.P. 2008. Late Paleoceneearly Eocene Tethyan carbonate platform evolution A response to long- and short-term paleoclimatic change. Earth-Science Reviews, 90(3-4):71-102.

Scheibner, C., Speijer, R.P., and Marzouk, A.M. 2005. Turnover of larger Foraminifera during the Paleocene-Eocene Thermal Maximum and paleoclimatic control on the evolution of platform ecosystems. Geology, 33:493-496.

Schneider, L.J., Bralower, T.J., Kump, L.R., and Patzkowsky, M.E. 2013. Calcareous nannoplankton ecology and community change across the Paleocene-Eocene Thermal Maximum. Paleobiology, 39:628-647.

Schulte, P., Scheibner, C., and Speijer, R.P. 2011. Fluvial discharge and sea-level changes controlling black shale deposition during the Paleocene-Eocene Thermal Maximum in the Dababiya Quarry, Egypt. Chemical Geology, 285:167-183.

Self-Trail, J.M., Powars, D.S., Watkins, D.K., and Wandless, G.A. 2012. Calcareous nannofossil assemblage changes across the Paleocene-Eocene Thermal Maximum: Evidence from a shelf setting. Marine Micropaleontology, 92-93:61-80.

Self-Trail, J.M., Robinson, M.M., Edwards, L.E., Powars, D.S., Wandless, G.A., and Willard, D.A. 2013. Integrated stratigraphy of a shallow marine PaleoceneEocene boundary section, MCBR cores, Maryland (USA). American Geophysical Union 2013 Fall Meeting, PP23B-1968.

Sessa, J.A., Bralower, T.J., Patzkowsky, M.E., Handley, J.C., and Ivany, L.C. 2012. Environmental and biological controls on the diversity and ecology of Late Cretaceous through early Paleogene marine ecosystems in the U.S. Gulf Coastal Plain. Paleobiology, 38:218-239.

Sherborn, C.D. and Griffin, F.J. 1934. On the dates of publication of the natural history portions of Alcide d'Orbigny's 'Voyage Amérique Méridionale'. Annals and Magazine of Natural History, (10) 13(73):130134.

Siesser, W.G. 1983. Paleogene calcareous nannoplankton biostratigraphy: Mississippi, Alabama, and Tennessee. Mississippi Department of Natural Resources Bureau of Geology Bulletin, 125:1-61.

Singh, A.D. and Singh O.P. 2010. Potentiality of pteropods in reconstruction of the Quaternary climatic and oceanographic history of the Arabian Sea, Special Issue on 'Applied Micropaleontology', Gondwana Geological Magazine, 25:81-88.

Sluijs, A. and Brinkhuis, H. 2009. A dynamic climate and ecosystem state during the Paleocene-Eocene Thermal Maximum: inferences from dinoflagellate cyst assemblages on the New Jersey Shelf. Biogeosciences, 6:1755-1781. 
Sluijs, A., Bowen, G.J., Brinkhuis, H., Lourens, L.J., and Thomas, E. 2007. The Paleocene-Eocene Thermal Maximum super greenhouse: biotic and geochemical signatures, age models and mechanisms of global change, p. 323-350. In Williams, M., Haywood, A.M., Gregory, F.J., and Schmidt, D.N. (eds.), Deep-Time Perspectives on Climate Change: Marrying the Signal from Computer Models and Biological Proxies. The Micropalaeontological Society, Special Publications, London.

Sluijs, A., Brinkhuis, H., Crouch, E.M., John, C.M., Handley, L., Munsterman, D., Bohaty, S.M., Zachos, J.C., Reichart, G.J., Schouten, S., Pancost, R.D., Sinninghe Damsté, J.S., Welters, N.L.D., Lotter, A.F., and Dickens, G.R. 2008. Eustatic variations during the Paleocene-Eocene greenhouse world. Paleoceanography, 23:PA4216. doi: 10.1029/2008PA001615

Sluijs, A., Roij, L. van, Harrington, G.J., Schouten, S., Sessa, J.A., LeVay, L.J., Reichart, G.J., and Slomp, C.P. 2014. Warming, euxinia and sea level rise during the Paleocene-Eocene Thermal Maximum on the Gulf Coastal Plain: implications for ocean oxygenation and nutrient cycling. Climate of the Past, 10:1421-1439.

Speijer, R.P., Scheibner, C., Stassen, P., and Morsi, A.M.M. 2012. Response of marine ecosystems to deep-time global warming: a synthesis of biotic patterns across the Paleocene-Eocene thermal maximum (PETM). Austrian Journal of Earth Sciences, 150:6-12.

Stassen, P., Speijer, R.P., and Thomas, E. 2014. The unsettled puzzle of the Marlboro clays. Proceedings of the National Academy of Sciences of the United States of America, 111:E1066-E1067. Doi: 10.1073/ pnas.1321839111

Stassen, P., Thomas, E., and Speijer, R.P. 2012a. Restructuring outer neritic foraminiferal assemblages in the aftermath of the Palaeocene-Eocene thermal maximum. Journal of Micropalaeontology, 31:89-93. Doi: 10.1144/0262-821X11-026

Stassen, P., Thomas, E., and Speijer, R.P. 2012b. The progression of environmental changes during the onset of the Paleocene-Eocene Thermal Maximum (New Jersey Coastal Plain). Austrian Journal of Earth Sciences, 105:169-178.

Stassen, P., Thomas, E., and Speijer, R.P. 2012c, Integrated stratigraphy of the Paleocene-Eocene Thermal Maximum in the New Jersey Coastal Plain: towards understanding the effects of global warming in a shelf environment. Paleoceanography, 27:PA4210. doi:10.1029/2012PA002323

Stassen, P., Thomas, E., and Speijer, R. 2015. Paleocene-Eocene Thermal maximum environmental change in the New Jersey Coastal Plan: benthic foraminiferal biotic events. Marine Micropaleontology, 115:1-23.

doi:10.1016/j.marmicro.2014.12.001
Stolley, E. 1900. Ueber Diluvialgeschiebe des Londonthons in Schleswig-Holstein und das Alter der Molerformation jütlands, sowie das baltische Eozän überhaupt. Archiv für Anthropologie und Geologie Schleswig-Holsteinds und der benachbarten Gebiete, 3:105-146. (In German)

Thomas, E. 1989. Development of Cenozoic deep-sea benthic foraminiferal faunas in Antarctic waters. Geological Society, London, Special Publications, 47:283-296.

Thomas, E. 1998. Biogeography of the Late Paleocene benthic foraminiferal extinction p. 214-243. In Aubry, M.-P. Lucas, S.H., and Berggren, W.A. (eds.), Late Paleocene-Early Eocene Climatic and Biotic Events in the Marine and Terrestrial Records. Columbia University Press, New York.

Thomas, E. 2007. Cenozoic mass extinctions in the deep sea: What perturbs the largest habitat on Earth? , p. 1-13. In Monechi, S., Coccioni, R., and Rampino, M.R. (eds.), Large Ecosystem Perturbations: Causes and Consequences. Geological Society of America, Special Paper 424.

Thomas, E. and Shackleton, N.J. 1996. The PaleoceneEocene foraminiferal extinction and stable isotope anomalies, p. 401-441. In Knox, R.W., Corfield, R.M., and Dunay, R.E. (eds.), Correlation of the Early Paleogene in Northwest Europe. Geological Society Special Publication 101.

Watelet, A. and Lefèvre, T. 1885. Note sur des ptéropodes du genre Spirialis découverts dans le Bassin de Paris. Annales de la Société Malacologique de Belgique 15 (1880):100-103. (publication date 1885, following Dollfus and Ramond, 1885, p. 38). (In French)

Webb, A.E., Leighton, L.R., Schellenberg, S.A., Landau, E.A., and Thomas, E. 2009. Impact of PaleoceneEocene global warming on microbenthic community structure: using rank-abundance curves to quantify ecological response. Geology, 37:783-786

Willard, D.A., Aleman, W., Edwards, L.E., Farmer, J.R., and Self-Trail, J. M. 2009. Marine and terrestrial biotic response to climate variability across the Paleocene-Eocene boundary in the Mid-Atlantic region, USA. American Geophysical Union, Fall Meeting 2009: Abstract PP41A-1492.

Winguth, A., Thomas, E., and Winguth, C., 2012. Global decline in ocean ventilation, oxygenation and productivity during the Paleocene-Eocene Thermal Maximum - Implications for the benthic extinction. Geology, 40: 263-266

Wright, J.D. and Schaller, M.F. 2013. Evidence for a rapid release of carbon at the Paleocene-Eocene thermal maximum. Proceedings of the National Academy of Sciences, 110:15908-15913.

Zachos, J.C., Bohaty, S.M., John, C.M., McCarren, H., Kelly, D.C., and Nielsen, T. 2007. The PalaeoceneEocene carbon isotope excursion: constraints from individual shell planktonic foraminifer records. Philosophical Transactions of the Royal Society a-Mathe- 
matical Physical and Engineering Sciences, 365(1856):1829-1842.

Zachos, J.C., Dickens, G.R., and Zeebe, R.E. 2008. An early Cenozoic perspective on greenhouse warming and carbon-cycle dynamics. Nature, 451(7176):279283.

Zachos, J.C., Pagani, M., Sloan, L., Thomas, E., and Billups, K. 2001. Trends, rhythms, and aberrations in global climate $65 \mathrm{Ma}$ to present. Science, 292:686693. Doi: 10.1126/science.1059412.

Zachos, J.C., Röhl, U., Schellenberg, S.A., Sluijs, A., Hodell, D.A., Kelly, D.C., Thomas, E., Nicolo, M., Raffi, I., Lourens, L.J., McCarren, H., and Kroon, D. 2005. Rapid acidification of the ocean during the
Paleocene-Eocene Thermal Maximum. Science, 308(5728):1611-1615. Doi: 10.1126/science. 1109004

Zachos, J.C., Schouten, S., Bohaty, S., Quattlebaum, T., Sluijs, A., Brinkhuis, H., Gibbs, S.J., and Bralower, T.J. 2006. Extreme warming of mid-latitude coastal ocean during the Paleocene-Eocene Thermal Maximum: Inferences from TEX86 and isotope data. Geology, 34:737-740.

Zhou, X., Thomas, E., Rickaby, R.E.M., Winguth, A.M.E., and $\mathrm{Lu}$, Z. 2014. I/Ca evidence for upper ocean deoxygenation during the PETM. Paleoceanography, 29:964-975. Doi: 10.1002/2014PA002702. 